\title{
Ectomycorrhizal fungi from southern Brazil - a literature-based review, their origin and potential hosts
}

\section{Sulzbacher MA ${ }^{1^{*}}$, Grebenc, $\mathbf{T}^{2}$, Jacques $\mathbf{R J S}^{3}$ and Antoniolli $\mathbf{Z I}^{3}$}

${ }^{1}$ Universidade Federal de Pernambuco, Departamento de Micologia/CCB, Av. Prof. Nelson Chaves, s/n, CEP: 50670901, Recife, PE, Brazil

${ }^{2}$ Slovenian Forestry Institute Vecna pot 2, SI-1000 Ljubljana, Slovenia

${ }^{3}$ Universidade Federal de Santa Maria, Departamento de Solos, CCR Campus Universitário, 971050-900, Santa Maria, RS, Brazil

Sulzbacher MA, Grebenc T, Jacques RJS, Antoniolli ZI 2013 - Ectomycorrhizal fungi from southern Brazil - a literature-based review, their origin and potential hosts. Mycosphere 4(1), 6195, Doi $10.5943 /$ mycosphere/4/1/5

A first list of ectomycorrhizal and putative ectomycorrhizal fungi from southern Brazil (the states of Rio Grande do Sul, Santa Catarina and Paraná), their potential hosts and origin is presented. The list is based on literature and authors observations. Ectomycorrhizal status and putative origin of listed species was assessed based on worldwide published data and, for some genera, deduced from taxonomic position of otherwise locally distributed species. A total of 144 species (including 18 doubtfull species) in 49 genera were recorded for this region, all accompanied with a brief distribution, habitat and substrate data. At least 30 collections were published only to the genus level and require further taxonomic review.

Key words - distribution - habitat - mycorrhiza - neotropics - regional list

Article Information

Received 28 November 2012

Accepted 20 December 2012

Published online 10 February 2013

*Corresponding author: MA Sulzbacher - e-mail - marcelo_sulzbacher@yahoo.com.br

\section{Introduction}

Ectomycorrhizal fungi (ECM) and their partner trees are well studied around the globe. Nevertheless, Europe, North America and several tropical regions have been considerably more explored while ECM dominated habitats in South America, Southeast Asia, Africa, and Australia remain relative undersampled (Tedersoo et al. 2010). In Brazil little is known about the ECM communities. Among the sporocarp-based studies of ECM conducted in Brazil, focusing both on native as well as exotic woody plants, we refer mainly to the work of Singer \& Araújo (1979), Singer et al. (1983) and Singer \& Aguiar (1986) in the Amazon region. Recent publications with surveys of putative ECM in exotic and native plantations throughout the country have contributed to the knowledge of this group in different areas, producing new records and newly described species (Baseia \& Milanez 2000, 2002, Gurgel et al. 2008, Menolli et al. 2009a, 2009b, Wartchow \& Maia 2007, Wartchow et al. 2009, Wartchow \& Cavalcanti 2010, Wartchow et al. 2012a, Wartchow 2012a, 2012b). All of these works are 
taxonomic and they do not confirm the association between plant and fungi.

Henkel et al. (2012) presented a comprehensive study of the diversity of ectomycorrhizal fungi sporocarps in the Guiana Shield. Neves \& Capelari (2007) published a Brazilian checklist of Boletales, reporting 20 genera and 70 species belonging to Boletales sensu Kirk et al. (2001), excluding the Sclerodermataceae. In a recent checklist Trierveiler-Pereira \& Baseia (2009) reported 232 taxa of Brazilian gasteroid fungi. In southern Brazil, the first contributions were made by Johannes Rick during the first half of the twentieth century (reviewed in Fidalgo 1962, Mauhs 2000). In the 1950s, Rolf Singer reviewed some of the species collected by Rick, named Fungi Rickiani (Singer 1953a). Several studies have added to the knowledge of ECM fungi in Brazil. Putzke (1994) has provided a checklist for the Brazilian Agaricales, listing 1,011 taxa. Many genera published by Putzke remain unresolved and need additional taxonomic confirmation.

Most of these contributions were checked by means of morphological features of the sporocarps. Nowadays, however, systematics and taxonomy of ECM fungi have been under profound changes, mainly due to the use of molecular tools (Binder \& Hibbett 2002, Binder \& Hibbett 2006, Hibbett et al. 1997, Hibbett 2006, Hosaka et al. 2006, Matheny et al. 2006, Miller et al. 2006, Moncalvo et al. 2002, 2006). Despite the fact, data on tropical and subtropical fungi were rarely included in DNA-based studies, compromising the knowledge about the identification and phylogenetic placement of those fungi (Rinaldi et al. 2008).

Brazil is the fifth largest country in the world, with more than 8.5 million $\mathrm{km}^{2}$, with two recognized hotspots for the conservation of biodiversity, the Atlantic Forest and the Cerrado (Myers et al. 2000). The southern part of Brazil is characterized by two domains, Atlantic Forest and Campos Sulinos or southern grasslands (Fiaschi \& Pirani 2009). The Atlantic forest is characterizated by high species diversity and endemism. It includes different forest types: dense ombrophilous forest, mixed ombrophilous forest (including Araucaria forest), seasonal deciduous and semi-desciduous forest, as well as pionner vegetation (de Meijer 2008, Veloso et al. 1991). The Campos Sulinos (or Pampa) biome is covered by open grassy formations, used as natural pastures (Fiaschi \& Pirani 2009). It is estimated that there are around 3,000 grassland species which belong mainly to the botanical families Poaceae, Asteraceae, Cyperacea, Fabaceae, Apiacea, Oxalidaceae, Verbanaceae, and Iridaceae. The main forest formations in Campus Sulinos are found at the Northern limit of the biome, in the transition area to Atlantic Rain Forest. In other regions, plant formations with trees are found mainly as gallery forests (islands of trees within the grassland) and shrub forests (Overbeck et al. 2006, 2007). A particular habitat for ECM fungi is forest tree plantations. Currently more than 5.98 Mha are planted with pine, eucalypts and acacia monocultures in Brazil (SBS 2008).

The central, western and northern regions of Brazil have a tropical climate with high annual temperatures averaging near $25^{\circ} \mathrm{C}$ with rainfall characterized by a wet season from October to March and a dry season from April to September (Rocha et al. 2009, Vourlitis et al. 2002). In the south of Brazil the subtropical climate is defined by four seasons and uniform annual rainfall. In this region, maximum average temperatures reach $30^{\circ} \mathrm{C}$, and average minimum temperatures in the winter are around $5^{\circ} \mathrm{C}$ (annual averages near $18^{\circ} \mathrm{C}$ ). As a consequence of its subtropical climate, this region has less intemperized soil than tropical Brazil and higher organic carbon content (Dieckow et al. 2009).

In view of the differences in climate, soil and vegetation in the Southern part of Brazil, this survey aimed to provide information on the diversity of ECM fungi in Southern Brazil (Paraná, Santa Catarina and Rio Grande do Sul), including a summary of information on putative hosts, nativeness, and a literature-based review of the area of origin. This study will, potentially, facilitate future studies on the systematics and biogeography of ECM fungi in Brazil.

\section{Methods}

The checklist and meta-analyses were based on a literature survey of scientific papers citing species of putative ectomycorrhizal fungi 
from Southern Brazil. The following information was retrieved: distribution of each recorded species (per state), potential ECM partners, the nativeness or potential origin, general habitat requirements and known substrates. The ectomycorrhizal status for each species is based either on the available description of ectomycorrhizae or on the taxonomic position of the species (Rinaldi et al. 2008, Tedersoo et al. 2010). The list and correlations also include several records by Rick (1961a, b) which may represent nomina dubia, synonyms or species of other genera.

Genera and species are listed alphabetically according to the MycoBank database (http://www.mycobank.org/MycoTaxo.aspx), and the Index Fungorum (http://www.indexfungorum.org/names/names. asp). The authority of the species names are given as in the original publications. The area of 'Southern Brazil' included in the study is represented by the States of Rio Grande do Sul (RS), Santa Catarina (SC) and Paraná (PR).

\section{Results and Discussion}

The following ECM fungi have been recorded from Southern Brazil.

Alnicola spadicea (D.A. Reid) Bon

Distribution - PR - Rio Negro. terricolous.

Habitat and substrate - planted Salix; 2006: 11).

Literature - de Meijer (2001: 113,

Comments - The genus Alnicola Kühner, includes 60 specific taxa, all mycorrhizal and mainly associated with Betulaceae and Salicaceae, most species originally described from Europe and later revised by Moreau (2005). The number of endemic species is undoubtedly large. Although, with our growing knowledge of the tropical fungi of other continents, the 'neotropical' and endemic element is bound to become gradually less conspicuous in the lists of native South American species. Examples of truly native species of the La Plata region seem to be Alnicola devia, Crepidotus tigrensis, Paxillus argentinus, Friesula platensis, but their precise area in South America cannot yet be determined (Singer 1953b, Moreau 2005).
Amanita chrysoleuca Pegler

Distribution - PR - Antonina.

Habitat and substrate - dense ombrophilous forest; terricolous.

Literature - de Meijer (2006: 11).

Comments - this species is apparantly distributed in (sub) tropical America. It was cited from the US Virgin Islands (Miller et al. 2000).

Amanita grallipes Bas \& de Meijer

Distribution - PR - Curitiba.

Habitat and substrate - mixed ombrophilous forest, seasonal semi-deciduous alluvial forest; terricolous.

Literature - Bas \& de Meijer (1993: 345), de Meijer (2001: 112, 2006: 11, 2008: 44, 140).

Comments - de Meijer (2008) refers that A. grallipes belongs to sect. Lepidella subsect. Vittadiniae Bas. It is not known if $A$. grallipes is ectomycorrhizal, but many species in the subsect. Vittadiniae are most certainly non-ectomycorrhizal. Wolfe et al. (2012) have shown that some species of Amanita (A. thiersii Bas) present saprotrophic nutrition.

Amanita muscaria (L.: Fr.) Lam. sensu lato Distribution - PR - Colombo; SC Correia Pinto, Joinville, Três Barras; RS Nova Petrópolis.

Habitat and substrate - plantations of Pinus taeda L.; terricolous.

Literature - de Meijer (2001: 113, 2006: 11, 2008: 142), Giachini et al. (2000: 1168), Guerrero \& Homrich (1999: 39), Karstedt \& Stürmer (2008: 1039), Sobestiansky (2005: 442), Stijve \& de Meijer (1993: 322).

Comments - this species has a global distribution, at least for the Southern hemisphere, due to human activities. As suggested by Wartchow (pers. comm.), A. muscaria growing under $P$. taeda corresponds to 'ssp. flavivolvata'.

\section{Amanita multisquamosa Peck}

Distribution - SC - Correia Pinto.

Habitat and substrate - plantations of Pinus taeda L.; terricolous.

Literature - Giachini et al. (2000: 1168, as A. pantherina var. multisquamosa (Peck) Jenkins). 
Comments - Amanita multisquamosa occurs in mixed coniferous and deciduous forest. In North America it occurs in the eastern parts and it may have been found in the Pacific Northwest as well (Jenkins 1986). This species appear to have mesophilous distribution in both Americas (continents).

Amanita petalinivolva Wartchow

Distribution - RS - Viamão.

Habitat - subtropical rain forest 'restinga'; terricolous.

Literature - Wartchow et al. (2012b).

Comments - The type for this taxon was collected in Brazil.

Amanita rubescens Pers.

Distribution - RS - Gramado.

Habitat and substrate - Pinus plantations; terricolous.

Literature - Sobestiansky (2005: 443).

Comments - It is common throughout much of Europe and eastern North America, growing on poor soils as well as in deciduous or coniferous woodlands. It has also been recorded from South Africa, where it is thought to have been accidentally introduced with trees imported from Europe (Reid \& Eicker 1991).

Amanita spissa (Fr.) Bertill.

Distribution - RS - locality unknown.

Habitat and substrate - unknown habitat; terricolous

Literature - Rick (1961a: 301).

Comments - Amanita spissa (and allies) is commonly found in Europe and eastern North America growing with both broad leaved as well as coniferous trees (Phillips 2006).

Amanita strobiliformis (Paulet ex Vittad.) Bertill.

Distribution - RS - locality unknown.

Habitat - unknown.

Literature Rick (1930, 1937, 1961a) all cited in Menolli et al. (2009b).

Comments - This species is predominantly distributed in Europe. It is more common in the Mediterranean region.
Austroboletus festivus (Singer) Wolfe

Distribution - PR - Paranaguá.

terricolous.

Habitat and substrate - 'restinga';

Literature - de Meijer (2001: 112), Singer et al. (1983: 137), Watling \& de Meijer (1997: 232).

Comments - The ectomycorrhizal status is based on it fruiting close to Ocotea pulchella (Nees \& Mart.) Mez, but a mycorrhizal connection has not been determined (Watling \& de Meijer 1997). Other potential plant hosts are Guettardia angelica Martius, Eschweilera ovata (Cambess.) Mart. ex Miers., and in particular, Hymenaea microphylla Barb. Rodr. (Singer et al. 1983). The genus Austroboletus is treated by Tedersoo et al. (2010) as potentially ectomycorrhizal based in its phylogenetic placement.

Boletinellus exiguus (Singer \& Digilio) Watling

Distribution - PR - Piraquara; RS Sapiranga.

Habitat and substrate - dense ombrophilous forest, mixed ombrophilous forest; terricolous, occurring on dead as well as living wood.

Literature - de Meijer (2001: 112, 2006: 12, 2008: 44, 130), Putzke et al. (1994: 82, as Gyrodon exiguus Singer \& Digilio), Watling \& de Meijer (1997: 243).

Comments - This species is putative ectomycorrhizal. It grows on soil, often in disturbed sites and it appears widely distributed in tropical America (Halling \& Mueller 1998, 2005). Also treated as Gyrodon exiguus (Singer et al. (1983) in Watling \& de Meijer (1997). Several species from the genus can alter root morphology (Gruhn et al. 1992) or are mycorrhizal (Gyrodon). However, to the best of our knowledge, no ectomycorrhizal association has been described for B. exiguus. The non obligatory ectomycorrhizal status of B. exiguous is discussed in de Meijer (2008).

Boletinellus rompelii (Pat. \& Rick) Watling Distribution - PR - Curitiba, Piraquara, São José dos Pinhais; RS - Liberato Salzano, 
Nova Petrópolis, Parecí, São Leopoldo, Viamão.

Habitat and substrate - mixed ombrophilous forest, seasonal semi-deciduous alluvial forest; terricolous.

Literature - de Meijer (2001: 112, 2006: 12, 2008: 44, 128), Putzke, et al. [1994: 81, as Gyrodon rompelii (Pat. \& Rick) Sing.], Singer (1953a: 101, as Phylloporus rompelii Pat. \& Rick, 117 and 128, as Gyrodon rompelii (Pat. \& Rick) Sing., Singer \& Digilio (1957: 256, as Gyrodon rompelii (Pat. et Rick) Sing.), Singer [1964: 118, as Gyrodon rompelii (Pat. \& Rick) Sing.], Sobestiansky (2005: 443), Watling \& de Meijer (1997: 243).

Comments - This species is facultatively ectomycorrhizal with Allophylus. It was recorded near Allophylus edulis (A.St.Hil. et al.) Hieron. ex Niederl., Trichilia elegans A. Juss. (Watling \& de Meijer 1997, de Meijer 2008), and near an Inga and Allophylus edulis site (Putzke et al. 1994). Singer (1953) referred to this species as ocurring near Acacia woods, while its mycorrhizal condition was discussed by Singer et al. (1983). Boletinellus rompelii ocurrs in South Texas, Mexico and South America (Bessette et al. 2000). No records have been published for Asia or Europe.

\section{Boletus edulis Bull.}

Distribution - RS - Gramado.

Habitat and substrate - Pinus plantations; terricolous.

Literature - Sobestiansky (2005: 443). Comments: Boletus edulis is widely distributed in the Northern Hemisphere across Europe, Asia, and North America. It does not occur naturally in the Southern Hemisphere, although it has been introduced to Southern Africa, Australia and New Zealand. In North America this species was described as Boletus edulis var. grandedulis with distribution linked to Pinus, Quercus and Abies spp. (Arora 2008). This species forms ectomycorrizae with a range of conifer and hardwood species (Agerer 19872006).

\section{Brauniella alba (Rick) Rick ex Singer} Leopoldo.

Distribution - RS - Cacequí, São

Habitat and substrate - on sandy earth.
Literature - Singer (1953a: 102 as Braunia alba Rick), Singer (1962: 66).

Comments: Brauniella is a South American genus and its mycorrhizal status remains unknown.

Calostoma zanchianum (Rick) Baseia \& Calonge

Distribution - RS - Cachoeira do Sul.

Habitat and substrate - unknown habitat; roots.

Literature - Baseia et al. (2006: 114, 2007: 278), Cortez (2009: 03), Rick (1961b: 456, as Mitremyces zanchianus Rick).

Comments - This species is considered putative ectomycorrhizal since its close relative C. cinnabarinum was proven to be mycorrhizal with oaks (Wilson et al. 2007). However, no direct evidence exists for the ectomycorrhizal status of $C$. zanchianum.

Cantharellus guyanensis Mont.

Distribution - PR - Campina Grande do Sul, Colombo, São José dos Pinhais.

Habitat and substrate - dense ombrophilous forest, mixed ombrophilous forest; unknown substrate.

Literature - de Meijer (2006: 13, 2008: 372).

Comments - Cantharellus guyanensis sensu Singer et al. (1983) form ECM (a typical mantle and Hartig-net was observed) with the roots of Glycoxylon inophyllum (Mart. ex Miq.) Ducke and Aldina heterophylla Spruce ex Benth., and possibly also with Psychotria and some Sapindaceae (Singer et al. 1983). This species was recorded in Guiana Shield region (Henkel et al. 2012). There are no records available on the distribution of this species for other continentes.

Cantharellus xanthoscyphus R. H. Petersen Distribution - PR - Antonina, Quatro Barras.

Habitat and substrate - dense ombrophilous forest; terricolous, occurring on dead wood. 2006: 13)

Literature - de Meijer (2001: 112,

Chalciporus piperatus (Bull.) Bataille

Distribution - PR - Curitiba; SC - 
Joinville, Três Barras.

Habitat and substrate - plantations of $P$. taeda; terricolous.

Literature - de Meijer (2001: 113, 2006: 13), Giachini et al. (2000: 1168); Karstedt \& Stürmer (2008: 1039, as Chalciporus cf. piperatus (Bull.: Fr.) Bat.); Watling \& de Meijer (1997: 233).

Comments - This species is potentially ectomycorrhizal (Rinaldi et al 2008, Watling \& de Meijer 1997). However, Tedersoo et al. (2010), suggest that there is no evidence that $C$. piperatus is ectomycorrhizal. Chalciporus piperatus, also frequently recorded as Boletus piperatus Bull. ex Fr., is distributed in America and Europe (Phillips 2006). It occurs in coniferous, beech and oak forests, while in New Zealand it was recorded with Nothofagus (Fuhrer \& Robinson 1992).

\section{Chondrogaster angustisporus Giachini, Castellano, Trappe \& V.L. Oliveira \\ Distribution - SC - Correia Pinto, Três Barras.}

Habitat and substrate - plantations of Eucalyptus dunnii Maid.; terricolous with hypogeous sporocarps. 1168)

Literature - Giachini et al. (2000:

Comments - Chondrogaster angustisporus is a hypogeous ectomycorrhizal fungus described from fruiting bodies collected under Eucalyptus spp. in Brazil, Uruguay and Australia (Giachini et al. 2000). In Europe this species was recorded in Spain (Lago \& Castro 2004) next to Eucalyptus globulus Labill.

\section{Chondrogaster pachysporus Maire}

Distribution - RS - Santa Maria.

Habitat and substrate - plantations of Eucalyptus saligna Sm.; terricolous with hypogeous sporocarps.

Literature - Sulzbacher et al. (2010: 378).

Comments - This species was recorded in Spain (Lago \& Castro 2004) next to Eucalyptus sp.

\section{Clavulina puiggarii (Speg.) Corner}

Distribution - PR - Antonina.

Habitat and substrate - dense ombrophilous forest; 'restinga'; terricolous.
Literature - de Meijer (2006: 14).

Comments: Clavulina puiggarii (Speg.) Corner is also known from the West Indies, South America, Malaysia and Australia (Henkel et al. 2011).

Coltricia barbata Ryvarden \& de Meijer

Distribution - PR - Antonina, Morretes, Paranaguá.

Habitat and substrate - dense ombrophilous forest; unknown substrate.

Literature - de Meijer (2006: 15).

Comments: Coltricia barbata is only known from the type locality in the State of Paraná (Baltazar et al. 2010).

\section{Coltricia cinnamomea (Jacq.) Murrill}

Distribution - PR - Curitiba, Guaraqueçaba, São Mateus do Sul.

Habitat and substrate - mixed ombrophilous forest, seasonal semi-deciduous alluvial forest, 'restinga' seasonal semideciduous alluvial forest; terricolous, occurring also in living wood.

Literature - de Meijer (2001: 113, 2006: 15, 2008: 372), Rajchenberg \& de Meijer (1990: 177, as Coltricia duportii).

Comments - Coltricia cinnamomea is a common and cosmopoliton polypore with records in North America (Phillips 2006), South America (Baltazar et al. 2010), Europe and Asia (Jülich 1984, Ryvarden 1976). This species is recorded as ectomycorrhizal (Tedersoo et al. 2010, Thoen 1993).

Coltricia duportii (Pat.) Ryvarden

Distribution - PR - Morretes.

Habitat and substrate - dense ombrophilous forest; unknown substrate.

Literature - de Meijer (2006: 15).

Comments - This species is putative ectomycorrhizal (Tedersoo et al. 2008).

Coltricia perennis (L.) Murrill

Distribution - PR - Lapa.

Habitat and substrate - Pinus plantations; terricolous.

Literature - de Meijer (2001: 113, 2006: 15)

Comments - In Brazil, this species is only known from a Pinus plantation in the State of Paraná (Baltazar et al. 2010). 
Coltriciella oblectabilis (Lloyd) Kotl., Pouzar \& Ryvarden

Distribution - PR - Paranaguá.

Habitat and substrate - dense ombrophilous forest, 'restinga'; terricolous.

Literature - de Meijer (2001: 113, 2006: 15), Rajchenberg \& de Meijer (1990: 178).

Comments - Known from Brazil (de Meijer 2001, 2006, Rajchenberg \& de Meijer 1990) and the South-Eastern United States (Kotlába et al. 1984). Recent records were also published for China (Dai et al. 2001).

\section{Cortinarius castaneofulvus Cleland}

Distribution - SC - Três Barras.

Habitat and substrate - plantations of Eucalyptus dunnii; terricolous. 1168)

Literature - Giachini et al. (2000:

Comments - This species was first described from an eucalypt site in Australia (Cleland 1928). The only other collections known are from Brazil (Giachini et al. 2000).

Descomyces albellus (Massee \& Rodway) Bougher \& Castellano

Distribution - SC - Correia Pinto; RS Santa Maria.

Habitat and substrate - plantations of Eucalyptus dunnii and Eucalyptus spp.; terricolous.

Literature - Cortez et al. (2008a: 514), Giachini et al. (2000: 1168).

Comments - This species was originally delimited from Hymenogaster by Bougher and Castellano in Australia. Additional locations are also known for New Zealand (Bougher \& Castellano 1993). The species was formerly restricted to Australasia. Nowadays, however, it spreads to areas covered by Eucalyptus forest (Kirk et al. 2008).

Descomyces albus (Klotzsch) Bougher \& Castellano

Distribution - SC - Correia Pinto.

Habitat and substrate - plantations of Eucalyptus dunnii; terricolous. 1168)

Literature - Giachini et al. (2000:

Comments - Descomyces albus is recorded in Australia, Germany, New Zeland,
North Africa, Spain, UK and the USA (Keane et al. 2000, Moreno-Arroyo et al. 2005).

Descomyces giachinii Trappe, V.L. Oliveira, Castellano \& Claridge

Distribution - SC - Correia Pinto.

Habitat and substrate - plantations of Eucalyptus dunnii; terricolous.

Literature - Giachini et al. (2000: 1168).

Comments - The species is recorded from Australia, Brazil, the USA and New Zealand (Giachini et al. 2000).

Entoloma bloxamii (Berk. \& Broome) Sacc.

Distribution - PR - São José dos Pinhais, São Mateus do Sul.

Habitat and substrate - mixed ombrophilous alluvial forest, mixed ombrophilous montane forest; terricolous.

Literature - de Meijer (2006: 19, 2008: 271, 372).

Comments - In Europe, Asia and North America this species inhabits unimproved grasslands such as old meadows and hayfields and is known for its indication value of extensive grasslands (Newton et al. 2003). It is rare throughout Europe (ECCF 2001). Records were published also from other areas (e.g. Japan - Kasuya et al. 2010). In general this species is regarded as saprobic, although there are several representatives of this genus that can form mycorrhizae (Kasuya et al. 2010) or transitional structures as describes by Agerer \& Waller (1993). Species of Entoloma sect. Entoloma are suspected to be ectomycorrhizal (Noordeloos 2002, in de Meijer 2008).

Gloeocantharellus corneri (Singer) Corner Distribution - PR - Campina Grande do Sul.

Habitat and substrate - dense ombrophilous forest, mixed ombrophilous forest; terricolous.

Literature - de Meijer (2001: 112, 2006: 23, 2008: 372), Watling \& de Meijer (1997: 245).

Comments - The type for Gloeocantharellus corneri was collected in Brazil. The genus has been recorded in North and South America (Corner 1969). 
Gyroporus castaneus (Bull) Quél.

Distribution - RS - Pelotas.

Habitat and substrate - planted Quercus; terricolous.

Literature - Putzke et al. (1994: 79).

Comments: The species is commonly found in oak forests in continental Europe and in eastern North America while rare in western North America (Arora 1986, Phillips 2006).

Hebeloma sacchariolens Quél.

Distribution - PR - Almirante

Tamandaré, Rio Negro; RS - Nova Petrópolis.

Habitat and substrate - pasture, Pinus plantations, planted Salix; terricolous.

Literature - de Meijer (2001: 113, 2006: 24), Sobestiansky (2005: 447, as Hebeloma cf. sacchariolens Quél.).

Comments - Hebeloma sacchariolens is ectomycorrhizal (Marmeisse et al. 1997). In general Hebeloma species are rare in the tropics but common in temperate Notheren hemisphere (Singer 1986) with Salix and other broadleaf species.

\section{Hydnodon thelephorus (Lév.) Banker}

Distribution - PR - Antonina, Campina Grande do Sul, Curitiba, General Carneiro, Mandirituba, Morretes, Piraquara, São José dos Pinhais, São Mateus do Sul; RS Nova Petrópolis.

Habitat and substrate - dense ombrophilous forest, mixed ombrophilous montane forest, gallery forest in area of savanna; terricolous.

Literature - de Meijer (2001: 113, as Phellodon tenuis Baird, 2006: 24, 2008: 89, 372), Sobestiansky (2005: 447).

Comments: This species is putative ectomycorrhizal. It was noted as “ectomycorrhizal?" (Sobestiansky 2005).

Hymenogaster vulgaris Tul. \& C. Tul.

Distribution - RS - locality unknown.

Habitat and substrate - unknown habitat; terricolous.

Literature - Rick (1961b: 456).

Comments - In Spain this species occurs under Quercus ilex L. (Moreno-Arroyo et al. 2005).

Hysterangium affine Massee \& Rodway
Distribution - RS - Santa Maria.

Habitat and substrate - Eucalyptus plantations; terricolous.

Literature - Cortez et al. (2011a: 221).

Comments - Hysterangium affine is recorded from Australia (Beaton et al. 1985), North (Zeller \& Dodge 1929) and South America. It is widespread in Eucalyptus plantations (Cortez et al. 2011a).

Hysterangium australe Speg.

Distribution - RS - São Leopoldo.

Habitat and substrate - Eucalyptus plantations; terricolous.

Literature - Rick (1961b: 457).

\section{Hysterangium inflatum Rodway}

Distribution - RS - Santa Maria.

Habitat and substrate - Eucalyptus plantations; terricolous.

Literature - Cortez et al. (2011a: 221).

Comments - Hysterangium inflatum is frequently found in Eucalyptus forest in Australia (Beaton et al. 1985), New Zealand (Castellano \& Beever 1994), France and Ecuador (Castellano \& Muchovej 1996), Spain (Lago \& Castro 2004, Moreno-Arroyo et al. 2005), United States (Zeller \& Dodge 1929), South Europe (Montecchi \& Sarasini 2000). This species is widespread in Eucalyptus plantation (Cortez et al. 2011a).

\section{Hysterangium gardneri E. Fisch.}

Distribution - SC - Correia Pinto, Três Barras.

Habitat and substrate - plantations of Eucalyptus dunnii Maid.; terricolous.

Literature - Giachini et al. (2000: 1168).

Comments - Hysterangium gardneri has a wide distribution, growing especially in Eucalyptus plantations. Nouhra et al. (2008) cited this species from Argentina in plantations of Eucalyptus camaldulensis and E. cinerea.

Inocybe australiensis Cleland \& Cheel

Distribution - PR - São José dos Pinhais; SC - Correia Pinto.

Habitat and substrate - Eucalyptus plantations, plantations of Eucalyptus dunnii Maid.; terricolous.

Literature - de Meijer (2001: 113, 
2006: 26, both as Inocybe cf. australiensis Cleland \& Cheel), Giachini et al. (2000: 1168). Comments: Inocybe australiensis occurrs in Australia (Grgurinovic 1997).

Inocybe curvipes $\mathrm{P}$. Karst.

Distribution - PR - Colombo, Curitiba; RS - Nova Petrópolis, Santa Maria.

Habitat and substrate - Pinus plantations; terricolous.

Literature - Cortez \& Coelho (2005: 71), de Meijer (2001: 113, 2006: 26), Sobestiansky (2005: 448), Stijve \& de Meijer (1993: 321).

Comments - In Europe, Inocybe curvipes occurs with broadleaf species (birch, poplar, hazel) in rich, humic soils (Stangl 1991). In Africa it is seen close to exotic pine plantations (Buyck \& Eyssartier 1999), and in Australia on soil under introduced Quercus sp., Pinus radiata D. Don., and probably Salix sp. (Bougher \& Matheny 2011).

\section{Inocybe hyperythra Rick}

Distribution - RS - São Leopoldo.

Habitat and substrate - subtropical forest; terricolous.

Literature - Rick (1961a: 406, as I. hypererythra Rick), Singer (1953a: 94), Singer et al. (1983: 181).

Comments - Mycorrhizal. However, association and accompanying trees are unknown (Singer et al. 1983).

\section{Inocybe violaceolamellata Rick}

Distribution - RS - São Leopoldo.

Habitat and substrate - unknown habitat; terricolous, mossy trunk.

Literature - Rick (1961a: 407), Singer (1953a: 94).

Labyrinthomyces varius (Rodway) Trappe

Distribution - SC - Correia Pinto.

Habitat and substrate - plantations of Eucalyptus dunnii Maid.; terricolous. 1168)

Literature - Giachini et al. (2000:

Comments - The whole genus is primarilly distributed in Australia in association with Eucalyptus spp. (Kirk et al. 2008).
Laccaria amethystina Cooke

Distribution - SC - Correia Pinto.

Habitat and substrate - plantations of Eucalyptus dunnii Maid. and Pinus taeda L.; terricolous. 1168).

Literature - Giachini et al. (2000:

Comments - Laccaria amethystina is a common species in most temperate zones of Europe, Asia, Central, South, and eastern North America. It forms ectomycorrhiza with a variety of deciduous and coniferous trees, though it most commonly occurs associated with Fagales (Laessoe 1998, Mueller 1992).

Laccaria bicolor (Maire) P.D. Orton

Distribution - SC - Correia Pinto, Três Barras.

Habitat and substrate - plantations of Eucalyptus dunnii Maid. and Pinus taeda L.; terricolous. 1168).

Literature - Giachini et al. (2000:

Comments - Laccaria bicolor is found throughout the temperate zones of the world (Phillips 2006), and also in Australia (Dunstan et al. 1998).

Laccaria laccata (Scop.) Cooke var. laccata

Distribution - SC - Correia Pinto, Três Barras; RS - Canela, Ijuí, Pelotas, Porto Alegre, Rio Pardo, Santa Maria, Santa Vitória do Palmar, Vera Cruz.

Habitat and substrate - Pinus plantations, and plantations of $P$. taeda L., and Eucalyptus dunnii Maid.; terricolous.

Literature - Giachini et al. (2000: 1168); Guerrero \& Homrich (1999: 41); Putzke (1999: 09; 2003: 286, as Laccaria laccata (Scop.:Fr.) Ber. \& Br.).

Comments - Laccaria laccata is found often in poor soil. It is very common for the Northern temperate zones. It is ectomycorrhizal with Pinaceae, Fagaceae and Betulaceae across Europe and North America (Mueller 1991). It is recorded also from Australia, Costa Rica, South Africa and New Zealand (Arora 1986, Dunstan et al. 1998).

Laccaria laccata var. pallidifolia (Peck) Peck Distribution - SC - Córrego Grande, 
Rio Vermelho, Três Barras.

Habitat and substrate - Eucalyptus plantations, plantations of Pinus elliottii Engelm. and P. taeda L.; terricolous.

Literature - Giachini et al. (2000: 1168).

\section{Laccaria lateritia Malençon}

Distribution - PR - Colombo, Curitiba, São José dos Pinhais; SC - Três Barras; RS Barros Cassal, Nova Petrópolis, Porto Alegre, Rio Pardo, Salvador do Sul, São Francisco de Paula, Santa Cruz do Sul, Sinimbu, Vale do Sol, Venâncio Aires, Vera Cruz.

Habitat and substrate - Eucalyptus plantations, plantations of E. dunnii; terricolous.

Literature - de Meijer (2001: 113, 2006: 27, both as Laccaria fraterna (Cooke \& Massee) Pegler), Giachini et al. (2000: 1168), Guerrero \& Homrich (1999: 41, as L. fraterna), Putzke (1999: 08, 2003: 283, both as $L$. fraterna), Rick (1961a: 329, as Clitocybe laccata Scop.), Singer (1953a: 110, as L. tetraspora Sing.), Sobestiansky (2005: 448, as L. fraterna).

Comments - The Laccaria lateritia group is common in Australia forming mycorrhizas with a number of plants, but frequently associated with eucalypts (http://www.blueswami.com/laccaria_lateritia. html).

Laccaria proxima (Boud.) Pat.

Distribution - PR - Colombo; SC Três Barras; RS - Nova Petrópolis.

Habitat and substrate - Pinus plantations, plantations of $P$. taeda L.; terricolous.

Literature - de Meijer (2001: 113, 2006: 27), Giachini et al. (2000: 1168), Sobestiansky (2005: 448).

Comments - Laccaria proxima is ectomycorrhizal with pines in North America. It is also common in Europe and was introduced in New Zealand and Australia (Dunstan et al. 1998).

\section{Laccaria pumila Fayod}

Distribution - SC - Correia Pinto, Três Barras.
Habitat and substrate - plantations of Eucalyptus dunnii Maid. and P. taeda L.; terricolous.

Literature - Giachini et al. (2000: 1168).

Comments - Laccaria pumila is recorded from Europe, North America (Mueller 1991, 1992) and from Australasia (Vellinga 1986).

Laccaria tetraspora (Scop.) Fr.

Distribution - SC - Joinville; RS - São Leopoldo.

Habitat and substrate - Pinus plantations; terricolous.

Literature - Karstedt \& Stürmer (2008: 1039), Putzke (1999: 06, 2003: 280).

Laccaria tortilis (Bolton) Cooke

Distribution - SC - Correia Pinto, Três Barras.

Habitat and substrate - plantations of Eucalyptus dunnii Maid. and Pinus taeda L.; terricolous. 1168).

Literature - Giachini et al. (2000:

Comments - Laccaria tortilis is a common species in North America and Europe (Phillips 2006), but also recorded from Australia and New Zealand (Dunstan et al. 1998).

Lactarius argillaceifolius Hesler \& A.H. Sm. var. argillaceifolius

Distribution - SC - Joinville, Rio Vermelho.

Habitat and substrate - plantations of Pinus elliottii Engelm.; terricolous.

Literature - Giachini et al. (2000: 1168).

Comments - Lactarius argillaceifolius ocurrs in North America (USA, Canada) and Mexico, mainly associated with oaks (Hesler \& Smith 1979).

\section{Lactarius braunii Rick}

Distribution - RS - Porto Alegre, São Leopoldo.

Habitat and substrate - unknown habitat; terricolous.

Literature - Raithelhuber (1991: 190), Rick (1961a: 365), Singer (1953a: 84). 
Lactarius deliciosus (L.) Gray

Distribution - PR - Colombo; SC -

Correia Pinto; RS - "highlands" as Sobestiansky (2005: 448).

Habitat and substrate - Pinus plantations and $P$. taeda L.; terricolous.

Literature - de Meijer (2006: 27), Giachini et al. (2000: 1168), Guerrero \& Homrich (1999: 40), Sobestiansky (2005: 448).

Comments - Lactarius deliciosus is widely distributed in Europe, Asia and North America (Hesler \& Smith 1979). It has been introduced in Chile, Australia and New Zealand in association with Pinus radiata D. Don. plantations (Phillips 2006, Dunstan et al. 1998).

Lactarius fragilis (Burl.) Hesler \& A.H. Sm. var. fragilis Distribution: SC - Correia Pinto, Joinville, Três Barras.

Habitat and substrate - Pinus plantations, plantations of $P$. elliottii Engelm. and $P$. taeda L.; terricolous.

Literature - Giachini et al. (2000: 1168), Karstedt \& Stürmer (2008: 1039, as Lactarius cf. fragilis).

Comments - Lactarius fragilis is found in North America, frequently with Douglas fir (Hesler \& Smith 1979).

\section{Lactarius paulensis Singer}

Distribution - PR - locality unknown.

Habitat and substrate: dense ombrophilous forest; terricolous, occurring on dead wood.

Literature - de Meijer (2001: 113).

Lactarius rufus (Scop.) Fr.

Distribution - PR - Mandirituba, Piraquara; SC - Correia Pinto, Três Barras; RS - Nova Petrópolis.

Habitat and substrate - Pinus plantations; plantations of $P$. taeda L.; terricolous.

Literature - de Meijer (2001: 114, 2006: 27), Giachini et al. (2000: 1168, as $L$. rufus var. rufus), Sobestiansky (2005: 448).

Comments - Lactarius rufus is frequent in Europe and North America, mostly with pines, birch, or spruce (Arora 1986).

Lactarius rufus var. parvus Hesler \& A.H. Sm.
Barras.

Distribution - SC - Correia Pinto, Três

Habitat and substrate - plantations of Pinus taeda L.; terricolous.

Literature - Giachini et al. (2000: 1168).

Lactarius russula Rick

Distribution - RS - São Leopoldo.

Habitat and substrate - forest; terricolous.

Literature - Rick (1961a: 364), Singer (1953a: 83), Singer et al. (1983: 311).

Lactarius venezuelanus Dennis

Distribution - PR - Antonina, Campina Grande do Sul, Morretes, Quatro Barras.

Habitat and substrate - dense ombrophilous forest, mixed ombrophilous forest; occurring on dead wood, terricolous.

Literature - Buyck \& de Meijer (1999: 270), de Meijer (2001: 113, 2006: 27, 2008: 372).

Comments - The species occurs under leguminous trees of campinarana vegetation (Buyck \& de Meijer 1999). The ectomycorrhizal status of this species is not clear. It also grows on the bases of living trees such as Sloanea (Elaeocarpaceae) and Talauma (Magnoliaceae) (Singer et al. 1983).

\section{Leucogaster braunii Rick}

Distribution - RS - São Leopoldo.

Habitat and substrate - Eucalyptus plantations; terricolous.

Literature - Rick (1961b: 455).

Comments - The genus was recognised as ectomycorrhizal from Australia (http://mycorrhizas.info/ecmf.html).

Modicella reniformis (Bres.) Gerd. \& Trappe

Distribution - SC - locality unknown.

Habitat and substrate - on or just under the leaf cover.

Literature - Thaxter (1922: 321, as Endogone reniformis Bres.).

Comments - This species forms endomycorrhiza (Trappe \& Schenck 1982).

Neopaxillus echinospermus (Speg.) Singer

Distribution - PR - Colombo, General Carneiro, São José dos Pinhais; RS - Couto 
(this locality is not in RS state, but probably in the state of Minas Gerais. Minas Gerais has the town of Couto de Magalhães de Minas, as referred by Maria Marchioretto from Instituto Anchietano de Pesquisas/UNISINOS (pers. com.).

Habitat and substrate - mixed ombrophilous montane forest and uppermontane and dense ombrophilous submontane forests; terricolous.

Literature - de Meijer (2001: 112, 2006: 35, 2008: 44, 131, 373), Singer (1950: 221, as Naucoria echinosperma Speg, 231, 1953a: 92, as Tubaria crobula Fr., 108, 1964: 114), Singer \& Digilio (1951: 436), Watling \& de Meijer (1997: 241).

Comments - Singer et al. (1983) noted that "this species is terrigenous and there is reason to believe that it is facultatively ectomycorrhizal although no convincing ecological or experimental data are available". Based on general observation on the genus Neopaxillus, de Meijer (2008) stated that it is not known if it is ectomycorrhizal or not. The genus is a member of Paxillaceae, associated with Araucaria forest (Issac et al. 1993). It has also been recorded from Sri Lanka (Issac et al. 1993). A similar species ( $N$. dominicanus Angelini \& Vizzini) was described recenty from the Dominican Republic (Vizzini et al. 2012).

Octaviania carnea (Wallr.) Corda.

Distribution - RS - locality unknown.

Habitat and substrate - unknown habitat; terricolous.

Literature - Rick (1961b: 457).

\section{Octaviania radicans $\mathrm{Rick}$}

Distribution - RS - locality unknown.

Habitat and substrate - unknown habitat; dead wood.

Literature - Rick (1961b: 457).

\section{Octaviania stillingerii Lloyd}

Distribution - RS - locality unknown.

Habitat and substrate - unknown habitat; terricolous.

Literature - Rick (1961b: 457).

\section{Paxillus alexandri Gillet.}

Distribution - RS - locality unknown.
Habitat and substrate - unknown habitat; pasture.

Literature - Rick (1961a: 405).

Comments - Paxillus alexandri was reported from several areas in Europe and North America published as a synonym Clitocybe alexandri (Gillet) Gillet. (Bigelow \& Smith 1962).

Paxillus involutus (Batsch) Fr.

Distribution - RS - São Salvador, São Leopoldo.

Habitat and substrate - subtropical forest; terricolous.

Literature - Guerrero \& Homrich (1999: 40), Rick (1961a: 404), Singer (1964: 112, as Paxillus aff. involutus).

Comments - Paxillus involutus is widely distributed across the Northern Hemisphere (incl. China, India, Japan and North America (Breitenbach \& Kränzlin 1991). It was also recorded in Greenland (Knudson 2006). It has been introduced to Australia, New Zealand, and South America with European trees. Paxillus involutus is treated as ectomycorrhizal with a range of coniferous and deciduous tree species (Taylor et al. 2000).

Phaeoclavulina cyanocephala (Berk. \& M.A. Curtis) Giachini

Distribution - PR - Colombo, Piraquara, Quatro Barras, São José dos Pinhais. Habitat and substrate - dense ombrophilous forest, mixed ombrophilous forest; terricolous.

Literature - de Meijer (2001: 112, as Ramaria grandis (Peck) Corner f. cyanocephala (Berk. \& Curtis) R.H. Petersen, 2006: 41, 2008: 99, 373, both as Ramaria cyanocephala (Berk. \& M.A. Curtis) Corner).

Phaeoclavulina pancaribbea (R.H. Petersen) Giachini

Distribution - PR - Piraquara.

Habitat and substrate - dense ombrophilous forest, mixed ombrophilous forest; terricolous.

Literature - de Meijer (2001: 112, 2006: 41, as Ramaria cf. pancaribbea R.H. Petersen f. caerulea R.H. Petersen).

Comments - Petersen (1988) described Ramaria pancaribbea var. zealandica which 
was recently renamed as Phaeoclavulina zealandica (R.H. Petersen) Giachini (Giachini \& Castellano 2011). Phaeoclavulina pancaribbea is considered putative ectomycorrhizal, yet likely to be ectomycorrhizal as other species from the genus (Agerer \& Rambold 2004-2010).

\section{Phaeoclavulina subclaviformis (Berk.)} Giachini

Distribution - PR - Campina Grande do Sul, Quatro Barras, Piraquara, São José dos Pinhais.

Habitat and substrate - dense ombrophilous forest, mixed ombrophilous forest, 'restinga'; terricolous.

Literature - de Meijer (2001: 112, 2006: 23, both as Gomphus subclavaeformis (Berk.) Corner, de Meijer 2008: 97, 372, as Gomphus cf. subclaviformis (Berk.) Corner.

\section{Phlebopus beniensis (Singer \& Digilio)} Heinem. \& Rammeloo

Distribution - PR - Paranaguá, Pontal do Paraná, Vera Cruz do Oeste.

Habitat and substrate - seasonal semideciduous submontane/montane forest, 'restinga'; terricolous.

Literature - de Meijer (2001: 112, 2006: 36), Watling \& de Meijer (1997: 235).

Comments - Phlebopus beniensis has been reported from Argentina, Bolivia, Brazil, Costa Rica, Ecuador and Martinique, in the neotropics, and from Liberia in Africa (Guzmán et al. 2007). In Brazil, specimens are found growing close to Laguncularia racemosa (L.) C.F. Gaertn. and Hibiscus tiliaceus L. (Watling \& Meijer 1997). Its mycorrhizal association remains doubtful (Singer et al. 1983). As Tedersoo et al. (2010), suggested that Phlebopus, as well as Boletinellus and Phylloboletellus are not ectomycorrhizal but facultatively or obligately biotrophic taxa.

Phlebopus braunii (Bres.) Heinem. Cruz. Distribution - RS - São Leopoldo, Vera

Habitat and substrate - subtropical forest; terricolous.

Literature - Putzke et al. (1994: 84).

Comments - The genus has a widespread distribution in subtropical and tropical regions, and contains 12 species. The species are saprobic, although some may be potentially able to form mycorrhizae with exotic trees in certain conditions (Kirk et al. 2008).

Phlebopus tropicus (Rick) Heinem. \& Rammeloo

Distribution - RS - São Leopoldo, Vera Cruz; SC - Itapiranga.

Habitat and substrate - subtropical forest; terricolous.

Literature - Putzke et al. (1994: 86), Singer (1950: 233, 1953a: 101, as Boletus tropicus Rick), Singer \& Digilio (1957: 253, as Phaeogyroporus tropicus (Rick) Singer).

Comments - This species is putative ectomycorrhizal, forming mycorrhiza with Allophylus spp. (Putzke et al. 1994). There is no evidence that this species forms typical ectomycorrhizae (Singer et al. 1983).

\section{Phyllobolites miniatus (Rick) Singer}

Distribution - RS - locality unknown.

Habitat and substrate - subtropical forest; terricolous.

Literature - Rick (1961a: 405 as Paxillus miniatus Rick), Singer (1953a: 93, 1964: 131), Singer et al. (1983: 30).

Comments - Singer et al. (1983) refer it under Leguminosae trees, as a putative ectomycorrhizal species. This is the only species in the genus found in tropical South America (Kirk et al. 2008).

Phylloporia spathulata (Hook.) Ryvarden

Distribution - PR - Campina Grande do Sul, Quatro Barras, São Mateus do Sul.

Habitat and substrate - dense ombrophilous forest, mixed ombrophilous forest, mixed ombrophilous alluvial forest, mixed ombrophilous montane forest; terricolous and on decayed wood, sometimes on the trunk base of an unidentified living Cyatheaceae tree. 373).

Literature - de Meijer (2006: 37, 2008:

Comments - This species is putative ectomycorrhizal (de Meijer, 2008). Phylloporia spathulata has a pantropical distribution (Wagner \& Ryvarden 2002). 
Pisolithus albus (Cooke \& Massee) Priest

Distribution - SC - Correia Pinto.

Habitat and substrate - plantations of Eucalyptus dunnii Maid.; terricolous.

Literature - Giachini et al. (2000:1168).

Comments - Pisolithus albus is a eucalyptus symbiont and has been found predominatly in Europe and North America, even though it originated from Australia (Bougher \& Syme 1998, Martin et al. 2002).

Pisolithus arhizus (Scop.) Rauschert

Distribution - RS - Capão do Leão,

Porto Alegre, Rio Grande, Santa Maria, Viamão.

Habitat and substrate - Eucalyptus plantations, plantations of Pinus elliottii Engelm., near Tabebuia heptaphylla (Vell.) Toledo; terricolous.

Literature - Guerrero \& Homrich (1999: 48, as Pisolithus tinctorius), Cortez (2011b: $45)$.

Comments - This species was refered by Cortez et al. (2011b) growing in eucalypt and pine (Pinus elliottii Engelm.) plantations as well near a native Tabebuia heptaphylla (Vell.) Toledo. The species is distributed in the Northern Hemisphere (Europe and North America). P. arhizus can be also found in the Southern Hemisphere, growing with introduced pine species (Martin et al. 2002).

Pisolithus microcarpus (Cooke \& Massee) G. Cunn.

Distribution - PR - Curitiba, São José dos Pinhais; SC - Córrego Grande, Rio Vermelho, Três Barras.

Habitat and substrate - Eucalyptus plantations, plantations of E. citriodora Hook., E. dunnii Maid., E. robusta Sm.; terricolous.

Literature - Giachini et al. (2000: 1169), de Meijer (2001: 114, as Pisolithus sp., 2006: 37, as Pisolithus cf. microcarpus (Cooke \& Massee) G. Cunn.).

Comments - Although now distributed with Eucalyptus plantations worldwide, $P$. microcarpus is considered to be a native Australian taxon (Martin et al. 2002).

Pisolithus pisiformis (Lloyd) Rick

Distribution - RS - locality unknown.

Habitat and substrate - unknown habitat; occurring on dead wood.

Literature - Rick (1961b: 459).

Ramaria anziana R.H. Petersen

Distribution - SC - Correia Pinto, Rio

Vermelho.

Habitat and substrate - Eucalyptus plantations; terricolous.

Literature - Giachini et al. (2000: 1168).

Comments - This species is native to Australia and New Zealand (http://www.gwannon.com/species/Ramaria-anziana).

Ramaria geesterani de Meijer Pinhais.

Distribution - PR - São José dos

Habitat and substrate - mixed ombrophilous montane forest; terricolous.

Literature - de Meijer (2008: 44, 101, 373).

Comments - de Meijer (2008: 103) concluded that the ectomycorrhizal status of all ten native species of Ramaria occurring in the state of Paraná is unknown despite the fact that the genus is generally considered ectomycorrhizal in Europe and North America (Agerer \& Rambold 2004-2010).

Ramaria junquilleovertex R.H. Petersen

Distribution - SC - Rio Vermelho.

Habitat and substrate - Eucalyptus plantations; terricolous.

Literature - Giachini et al. (2000: 1168).

Comments - Found in New Zealand, as native, on the ground under Leptospermum sp. and Nothofagus sp. Nationally critically threatened in New Zealand (McKenzie et al. 2006).

Ramaria moelleriana var moelleriana (Bres. \& Roum.) Corner Pinhais.

Distribution - PR - São José dos

Habitat and substrate - mixed ombrophilous montane forest; decayed dicotyledonous branch.

Literature - de Meijer (2008: 44, 373).

recorded

Comment - The species was also (http://malaysianfungi.webs.com). 
Ramaria toxica Toledo \& R.H. Petersen

Distribution - PR - Curitiba; RS Porto Alegre, "highlands and interior of Rio Grande do Sul" as Sobestiansky (2005: 453).

Habitat and substrate - Eucalyptus plantations; terricolous.

Literature - de Meijer (2001: 113, 2006: 41), Guerrero \& Homrich (1999: 51), Sobestiansky (2005: 453).

Comments - Ramaria toxica is referred to Argentina and Brazil under Eucalyptus (Toledo \& Petersen 1989).

Redeckera fulvum (Berk. \& Broome) C. Walker \& A. Schüßler

Distribution - (?) RS - locality unknown.

Habitat and substrate - occurring on dead bamboo debris, as well as under the leaf cover.

Literature - Thaxter (1922: 319, as Endogone fulva (Berk. \& Broome) Pat.

Comment: This species forms endomycorrhiza (Trappe \& Schenck 1982).

Rhizopogon fuscorubens A. H. Sm.

Distribution - SC - Correia Pinto, Rio Vermelho, Três Barras.

Habitat and substrate - plantations of $P$. elliottii Engelm. and P. taeda L.; terricolous. 1168).

Literature - Giachini et al. (2000:

Comments - Rhizopogon fuscorubens has been found in the United States (Smith \& Zeller 1966) under conifers especially pines (Pinus rigida Miller and $P$. contorta Douglas ex Loudon). Molina \& Trappe (1994) mentioned other probable ectomycorrhizal hosts: Arbutus menziesii Pursh, Arctostaphylos uva-ursi (L) Sprengel, Pinus monticola Douglas ex D. Don, P. ponderosa Douglas ex Lawson \& C. Lawson and $P$. serotina Michaux. The species was also recorded in Spain with an unknown host (Martín 1996).

Rhizopogon nigrescens Coker \& Couch

Distribution - SC - Rio Vermelho, Três Barras.

Habitat and substrate - plantations of $P$. elliottii Engelm. and P. taeda L.; terricolous. 1168).
Comments - Rhizopogon nigrescens was found in sandy soil under pines in the Southeastern USA (Bessette et al. 2007).

Rhizopogon roseolus (Corda) Th. Fr.

Distribution - PR - Colombo, Curitiba; SC - Correia Pinto, Três Barras; RS - Itaara, Santa Maria.

Habitat and substrate - Pinus plantations, plantations of $P$. taeda L.; terricolous.

Literature - Cortez (2011b: 45), de Meijer (2001: 113, as R. luteorubescens A.H. Sm.; 2006: 41, as Rhizopogon roseolus (Corda) Th. Fr. sensu Martín (1996) or $R$. luetorubescens A.H. Sm.), Giachini et al. (2000: 1168, as Rhizopogon rubescens (Tul. \& C. Tul.) Tul. \& C. Tul. and Rhizopogon vulgaris (Vittad.) M. Lange).

Comments - Rhizopogon roseolus is the species most common in Europe. The basidiomes are semihypogeous on sandy or calcareous soil in association with Abies spp., Picea spp., Pinus spp. and also under Quercus spp. (Martín et al. 2000). $R$. roseolus (synonym Rhizopogon rubescens Tul.), an economically important edible mushroom associated with the Pinaceae (mostly Pinus sp.), has a global distribution. In the Southern Hemisphere it results from the introduction of exotic trees in reforestation programs (Visnovsky et al. 2010).

Rhizopogon zelleri A.H. Sm.

Distribution - SC - Três Barras.

Habitat and substrate - plantations of $P$. taeda; terricolous.

Literature - Giachini et al. (2000: 1168).

Comments - Rhizopogon zelleri is native to North America where the type was collected by Zeller in 1966 in pure or mixed pine forests (Martín 1996).

Russula consobrina (Fr.) Fr.

Distribution - PR - São José dos Pinhais; RS - Nova Petrópolis.

Habitat and substrate - Pinus plantations; terricolous.

Literature - de Meijer (2001: 114, 2006: 42), Sobestiansky (2005: 453).

Comments - It grows in coniferous forests, in association with Picea. Widespread in Europe. In the USA known from the 
Northwest under conifers. Also recorded in China (Zhishu et al. 1993).

\section{Russula puiggarii (Speg.) Singer}

Distribution - PR - Campina Grande do Sul, Quatro Barras, Morretes, Piraquara; RS São Leopoldo.

Habitat and substrate - dense ombrophilous forest, mixed ombrophilous forest; terricolous, sandy soil, occurring on dead or rotten wood.

Literature - de Meijer (2001: 113, 2006: 42, 2008: 373), Rick (1961a: 363, as $R$. pectinata (Bull.) Fr.), Singer \& Digilio (1951: 442), Singer (1953a: 83, as R. pectinata (Bull.) Fr.), Singer et al. (1983: 214).

Comments - Occurring in all types of rain forests, mainly in the tropical lowlands, probably non-mycorrhizal or only facultatively mycorrhizal (Singer et al. 1983). Haug et al. (2005) observed $R$. puiggarii forming a mantle and a Hartig's net in roots of Neea sp. (Nyctaginaceae).

\section{Russula riograndensis Singer}

Distribution - RS - São Leopoldo. terricolous.

Habitat and substrate - forest; Literature - Rick (1961a: 363, as $R$. subfragilis Rick), Singer (1953a: 81, as $R$. subfragilis), Singer et al. (1983: 236, as $R$. subfragilis).

\section{Russula theissenii Rick} Leopoldo.

Distribution - PR - Morretes; RS - São

Habitat and substrate - dense ombrophilous forest; terricolous.

Literature - de Meijer (2001: 113, 2006: 42, 2008: 373, both as Russula aff. theissenii Rick), Rick (1961a: 363), Singer (1953a: 81), Singer et al. (1983: 209).

Comments: The position and ecological significance of this species is not clear (Singer et al. 1983: 211).

\section{Russula velenovskyi Melzer \& Zvára}

Distribution - PR - locality unknown.

Habitat and substrate - planted Castanea sativa Mill.; terricolous.

Literature - de Meijer (2001: 114, 2006: 42)
Comments - The habitat of Russula velenovskyi is under broad-leaved trees and pine. It is found in Europe (Phillips 2006) with holarctic, subboreal and suboceanic species. The species is mycorrhizal with Fagales (Betula, Fagus, Carpinus, Quercus) and only rarely with conifers (Krieglsteiner et al. 2000).

\section{Sarcodon atroviridis (Morgan) Banker}

Distribution - PR - Colombo, General Carneiro, Quatro Barras, Morretes, Piraquara, São José dos Pinhais.

Habitat and substrate - dense ombrophilous forest, mixed ombrophilous montane forest; terricolous.

Literature - de Meijer \& Baird (1992: 639), de Meijer (2001: 113, 2006: 42, 2008: 373, both as Sarcodon bambusinus (R.E.D. Baker \& W.T. Dale) Maas Geest.

Comments - Ectomycorrhizal with leguminous trees (Singer et al. 1983). Sarcodon atroviridis ocurrs in mixed woods. Found in eastern and southeastern North America (Phillips 2006). Collections also known from Japan and India but probably introduced since collected in a botanical garden (Leelavathy et al. 1986).

Scleroderma albidum Pat. \& Trab.

Distribution - SC - Córrego Grande, Correia Pinto, Rio Vermelho, Três Barras; RS - Capitão, Minas do Leão, Pareci Novo, Rio Grande, Santa Cruz do Sul, Santa Maria, São Leopoldo, Viamão.

Habitat and substrate - Eucalyptus plantations, plantations of Pinus elliottii Engelm. and $P$. taeda L.; terricolous.

Literature: Cortez et al. (2008b: 293), Cortez (2011b: 47), Giachini et al. (2000: 1169), Guzmán (1970: 301).

Comments - Scleroderma albidum occurs in SW Australia (http://bie.ala.org.au/species/urn:1sid:biodiversi ty.org.au:apni.taxon:268116) and Argentina with introduced pine and eucalypts species (Nouhra et al. 2012). In Brazil this species is frequently collected under Eucalyptus spp., and according to Cortez et al. (2011b) is apparently associated with several other tree species.

Scleroderma areolatum Ehrenb. Distribution - SC - Córrego Grande, 
Correia Pinto, Rio Vermelho, Três Barras.

Habitat and substrate - Eucalyptus plantations; terricolous. 1169).

Literature - Giachini et al. (2000:

Comments - This species is mycorrhizal with hardwoods and conifers in moist, shady woods. S. areolatum is widely distributed in Europe (Fagus, Pinus) and North America (Castanea) (Phillips 2006). In Argentina recorded under planted Pinus spp., Populus sp. and Quercus sp. (Nouhra et al. 2012).

Scleroderma bougheri Trappe, Castellano \& Giachini

Distribution - SC - Correia Pinto, Rio Vermelho, Três Barras.

Habitat and substrate - Eucalyptus plantations; terricolous. 1169).

Literature - Giachini et al. (2000:

Comments - Scleroderma bougheri is a hypogeous ectomycorrhizal fungus described from Australia and Brazil (Giachini et al. (2000).

\section{Scleroderma bovista Fr.}

Distribution - SC - Córrego Grande, Correia Pinto, Joinville, Rio Vermelho, Três Barras; RS - Porto Alegre, Santa Maria.

Habitat and substrate - Eucalyptus plantations, plantations of Pinus elliottii Engelm., and P. taeda L.; terricolous.

Literature - Cortez (2011b: 47), Giachini et al. (2000: 1169), Guzmán (1970: 344 , the author did not mention the name of the state but the collector is Rick).

Comments - Scleroderma bovista occurs in Europe and North America usually in hardwood forests. In Argentina it has been observed with exotic planted trees (Nouhra et al. 2012). The species was also recorded in New Zealand (Dunstan et al. 1998). In Brazil the species was found growing associated with a native tree (Gomidesia spectabilis [DC.] Berg.) in the northeast (Gurgel et al. 2008).

\section{Scleroderma cepa Pers.}

Distribution - SC - Correia Pinto.

Habitat and substrate - plantations of Eucalyptus dunnii Maid.; terricolous. 1169).

Literature - Giachini et al. (2000:

Comments - Scleroderma cepa is a widespread ectomycorrhizal species on hardwoods (Quercus, Populus), found in North America (Coker \& Couch 1928), South Africa (Bottomley 1948) and Australia (under Eucalyptus

http://australianfungi.blogspot.com/2010/07/39 -scleroderma-cepa.html).

\section{Scleroderma citrinum Pers.}

Distribution - PR - Castro; SC Córrego Grande, Correia Pinto, Joinville, Rio Vermelho, Três Barras; RS - Nova Petrópolis, Santa Maria, São Francisco de Paula, São Leopoldo.

Habitat and substrate - Pinus plantations, plantations of $P$. elliottii Engelm. and $P$. taeda L.; occurs in living wood, terricolous.

Literature - Cortez (2011b: 47), de Meijer (2001: 114, 2006: 43), Giachini et al. (2000: 1169), Rick (1961b: 458, as Scleroderma vulgare Hornem.), Sobestiansky (2005: 453).

Comments - Scleroderma citrinum is common in Europe, also recorded in South America, South Africa and New Zealand (Dunstan et al. 1998). The species is ectomycorrhizal with a range of broadleaf species and conifers.

\section{Scleroderma dictyosporum Pat.}

Distribution - RS - Santa Maria.

Habitat and substrate - near Acacia caven (Molina) Molina; terricolous.

Literature - Cortez et al. (2011b: 49).

Comments - Cortez et al. (2011b) reported this species distributed across dry regions of Africa, Asia and America, as well as the subtropical zone. The Brazilian specimens were found growing near the base of Acacia caven (Molina) Molina, a native species from Southern South America. Authors also reported that in Africa $S$. dictyosporum has been found as an ectomycorrhizal partner of other acacia species, such as A. holosericea A.Cunn. ex G. Don, and A. mangium Willd. (see also Founoune et al. 2002, Duponnois et al. 2005, Sanon et al. 2009). Scleroderma dictyosporum is ectomycorrhizal with Afzelia africana Sm. 
from West Africa (Ba \& Thoen 1990) and with Uapaca guineensis Müll. Arg., from Southern Senegal (Thoen \& Ba 1989). It has also been described associated with Eucalyptus from Congo (Garbaye et al. 1988).

\section{Scleroderma floridanum Guzmán}

Distribution - SC - Córrego Grande, Correia Pinto, Rio Vermelho, Três Barras.

Habitat and substrate - Eucalyptus plantations, plantations of Pinus elliottii Engelm. and P. taeda L.; terricolous. 1169).

Literature - Giachini et al. (2000:

Scleroderma fuscum (Corda) E. Fisch.

Distribution - RS - Porto Alegre, Santa Maria; SC - Correia Pinto, Joinville, Rio Vermelho, Três Barras.

Habitat and substrate - plantations of Pinus elliottii Engelm. and P. taeda L.; terricolous.

Literature - Giachini et al. (2000: 1171), Cortez (2011b: 49).

Comments - Scleroderma fuscum forms ectomycorrhizae with Pinus spp. and is reported from several regions, including South America (Cortez et al. 2011b).

\section{Scleroderma laeve Lloyd}

Distribution - RS - Porto Alegre.

Habitat and substrate - Eucalyptus plantations; terricolous.

Literature - Cortez et al. (2011b: 49).

Comments - This species forms ectomycorrhizae with Eucalyptus spp. (Cortez et al. 2011b) in a non-specific manner (Malajczuk et al. 1982).

Scleroderma uruguayense (Guzmán) Guzmán

Distribution - SC - Córrego Grande, Correia Pinto, Rio Vermelho.

Habitat and substrate - plantations of

Pinus elliottii Engelm. and P. taeda L.; terricolous. 1169).

Literature - Giachini et al. (2000:

Scleroderma verrucosum (Bull.) Pers.

Distribution - PR - Colombo, Curitiba, São José dos Pinhais; SC - Córrego Grande;
RS - Nova Petrópolis, Santa Maria.

Habitat and substrate - pasture, plantations of Pinus elliottii Engelm., Eucalyptus plantations; terricolous.

Literature - Cortez et al. (2011b: 50), de Meijer (2001: 114, 2006: 43, as Scleroderma cf. verrucosum), Giachini et al. (2000: 1169), Rick (1961b: 458), Sobestiansky (2005: 454, as Scleroderma cf. verrucosum).

Comments: Scleroderma verrucosum is a cosmopolitan species (Guzmán 1970). It is commonly found in Europe in mixed or broadleaf forests. The species was introduced to New Zealand with Quercus spp. and Pinus radiata. $S$. verrucosum is ectomycorrhizal with Afzelia africana Sm., in West Africa (Ba \& Thoen 1990) and cultivated in Burkina Faso with the native vegetation - Uapaca somon (http://senegal.ird.fr). In Brazil it was reported from several States (Cortez 2011b).

Sclerogaster luteocarneus (Bres.) Zeller \& C.W. Dodge das Antas.

Distribution - PR - Fênix; RS - Poço

Habitat and substrate - seasonal semideciduous submontane/montane forest; on dead wood, terricolous.

Literature - de Meijer (2001: 113, 2006: 43), Dodge \& Zeller (1936: 570), Rick (1961b: 457, as Octaviania luteocarnea Bres.), Singer (1962: 54, as Sclerogaster cf. luteocarneus).

Comments - Sclerogaster luteocarneus is found in tropical America (Dodge \& Zeller 1936).

Setchelliogaster tenuipes (Setch.) Pouzar

Distribution - SC - Correia Pinto; RS Guaíba, Viamão.

Habitat and substrate - Eucalyptus plantations, plantations of E. dunnii Maid.; terricolous.

Literature - Cortez et al. (2008a: 514), Giachini et al. (2000: 1168).

Comments - Setchelliogaster tenuipes ocurs in Argentina (Nouhra et al. 2008), Australia (Grgurinovic 1997) and Europe (Montecchi \& Sarasini 2000). This species is associated with Eucalyptus spp. (Lago \& Castro 2004). 
Suillus cothurnatus Singer

Distribution - SC - Correia Pinto, Rio Vermelho, Três Barras; RS - Nova Petrópolis; PR - Colombo.

Habitat and substrate - Pinus plantations, plantations of $P$. elliottii Engelm., $P$. patula Schiede ex Schltdl. \& Cham. and $P$. taeda L.; terricolous.

Literature - de Meijer (2001: 113, 2006: 44), Giachini et al. (2000: 1168), Sobestiansky (2005: 454), Watling \& de Meijer (1997: 236).

Comments - Occurring in the vicinity of Pinus palustris Mill. or P. taeda L., though occasionally as far as $11 \mathrm{~m}$ from the nearest pine tree (Singer et al. 1983). S. cothurnatus is native to North America (Singer 1945).

\section{Suillus granulatus (L.) Kuntze}

Distribution - PR - Colombo; SC Córrego Grande, Correia Pinto; RS - Santa Cruz do Sul, Venâncio Aires.

Habitat and substrate - Pinus plantations, plantations of $P$. elliottii Engelm., $P$. patula Schiede ex Schltdl. \& Cham., $P$. taeda L.; terricolous.

Literature - de Meijer (2001: 113, 2006: 44), Giachini et al. (2000: 1168), Putzke et al. (1994: 90), Watling \& de Meijer (1997: 238).

Comments - Suillus granulatus grows with Pinus spp. on calcareous and acid soils, sometimes in large numbers. It is native to the Northern hemisphere and common in Britain, continental Europe, and North America. It has also been introduced to Australia (Phillips 2006), South Africa and New Zealand (Dunstan et al. 1998), probably with Pinus radiata D. Don.

\section{Suillus luteus (L.) Roussel}

Distribution - PR - Colombo; RS Canela, Nova Petrópolis, Pelotas.

Habitat and substrate - Pinus plantations, plantations of $P$. elliottii Engelm.; terricolous.

Literature - de Meijer (2001: 113, 2006: 44), Putzke et al. (1994: 88), Sobestiansky (2005: 454), Watling, de Meijer (1997: 238).

Comments - Suillus luteus is found in the Northern hemisphere. It is common in pine plantations, especially young forests. The species forms mycorrhizal with various Pinus species, including $P$. sylvestris L., $P$. nigra J.F.Arnold or $P$. peuce Griseb. in Europe, and $P$. resinosa Sol. ex Aiton and P. strobus L. in North America. It has also been introduced with pines to Australia, New Zealand and Argentina (Moser 1980). Singer (1945, 1949) and Putzke et al. (1994) refer this species as occurring only in $P$. nigra J.F. Arnold, $P$. pinea L., $P$. silvestris $L$. and $P$. resinosa Sol. ex Aiton.

\section{Suillus subaureus (Peck) Snell}

Distribution - RS - Vera Cruz.

Habitat and substrate - Pinus plantations; terricolous.

Literature - Putzke et al. (1994: 91).

Comments - Suillus subaureus is mycorrhizal with Populus spp., Quercus berberidifolia Liebm and Pinus strobus L. in North America (Roody 2003).

\section{Thelephora americana Lloyd}

Distribution - SC - Rio Vermelho, Três Barras.

Habitat and substrate - Eucalyptus plantations, plantations of Pinus elliottii Engelm. and P. taeda L.; terricolous.

Literature - Giachini et al. (2000: 1169).

Comments - Thelephora americana is ectomycorrhizal with Abies alba Mill. based on a sequence similarity search (Grebenc et al. 2009). The species occurs in Canada, USA, Mexico, Japan and China (Corner 1968).

Thelephora griseozonata Cooke

Distribution - SC - Rio Vermelho.

Habitat and substrate - Eucalyptus plantations; terricolous. 1169).

Literature - Giachini et al. (2000:

Comments - Thelephora griseozonata is indigenous to New Zealand, but also found in North America under pines.

Thelephora palmata (Scop.) Fr.

Distribution - PR - Pontal do Paraná.

Habitat and substrate: 'restinga'; occurring on dead wood.

Literature - Meijer (2001: 113, 2006: 
44).

Comments - Thelephora palmata is common in Europe and North America (Phillips 2006), mainly in coniferous woods. It is regarded as common in the North temperate zone. According to Chen et al. (2001), the species is ectomycorrhizal.

\section{Thelephora terrestris Ehrh.}

Distribution - PR - General Carneiro; SC - Rio Vermelho, Três Barras.

Habitat and substrate - Eucalyptus plantations, Pinus plantations, plantations of $P$. taeda L.; terricolous, occurring on dead wood. Literature: de Meijer (2001: 114, 2006: 44), Giachini et al. (2000: 1169), Guerrero \& Homrich (1999: 46).

Comments - Thelephora terrestris is known from Europe, North America, Japan, China, Jamaica, Brazil, Uruguay, Australia, New Zealand and South Africa. It occurs either on the ground in coniferous woods, saprophytic, mycorrhizal on Betula, Picea, Pinus and Eucalyptus (Agerer 1987-2008) or semi-parasitic (sensu Corner 1968). Thelephora terrestris was introduced to Australia during the establishment of exotic pines (Corner 1968). Malajczuk et al. (1982) reviewed host-sporocarp records and concluded that several fungal associates of pine, such as T. terrestris, were absent from eucalypt stands.

Tricholoma atrosquamosum Sacc.

Distribution - PR - Colombo.

Habitat and substrate - Eucalyptus plantations; unknown substrate.

Literature - de Meijer (2006: 45).

Comments - Tricholoma atrosquamosum is native in Europe and has been also collected in North America (Phillips 2006). This species can be found in deciduous (Fagus spp., Quercus spp.) and coniferous (Pinus spp., Picea spp.) stands, mainly on calcareous soils. The species was also identified from roots of the heterotrophic plant Pityopus californicus (Eastwood) H. F. Copel., and from California, USA (Bidartondo \& Bruns 2001).

\section{Tricholoma sulphurellum Rick}

Distribution - RS - Esmeralda.

Habitat and substrate - Araucaria forest; terricolous.
Literature - Putzke (2003: 579); Rick (1961a: 304); Singer (1953a: 64); Singer et al. (1983: 173), Sulzbacher et al. (2007: 146).

Comments: Singer et al. (1983) pointed out the possibility of this species being ectomycorrhizal since it is a member of the section Sericella (Fr.) Quél. (= Sericeocutis Singer), a section known to contain ectomycorrhizal species.

Tricholoma vaccinum (Schaeff.) P. Kumm.

Distribution - RS - locality unknown.

Habitat and substrate - forest; unknown substrate.

Literature - Rick (1961: 304).

Comments - Tricholoma vaccinum is mycorrhizal with conifer, especially Picea spp. and Pinus spp. It is common in Europe and widely distributed in the Northern portion of the Northern Hemisphere. In North America it is common in the Rockies and the Pacific Northwest (Trudell \& Ammirati 2009).

Xerocomus basius de Meijer \& Watling Distribution - PR - Campina Grande do Sul, Colombo, Curitiba, São José dos Pinhais.

Habitat and substrate - dense ombrophilous forest, mixed ombrophilous montane forest; terricolous.

Literature - de Meijer (2008: 44, 125, 373).

Comments - the species ectomycorrhizal status is unknown (de Meijer 2008). According to Tedersoo et al. (2010), Xerocomus is an ectomycorrhizal genus.

Xerocomus brasiliensis (Rick) Singer

Distribution - RS - Nova Petrópolis, São Leopoldo.

Habitat and substrate - open places among Gramineae, subtropical and tropical forest, Eucalyptus plantations; terricolous, on rotten wood.

Literature - Gómez (1996: 61), Putzke et al. (1994: 92), Singer \& Digilio (1957: 260), Singer et al. (1983: 65), Singer (1953a: 100, as Boletus brasiliensis Rick, 101, as Phylloporus flavipes Rick), Sobestiansky (2005: 443, as Boletus brasiliensis).

Comments - Xerocomus brasiliensis forms mycorrhiza with Eucalyptus (Singer et al. 1983) or is regarded as a putative 
ectomycorrhizal fungus (Sobestiansky 2005). According to Tedersoo et al. (2010) the genus is ectomycorrhizal.

Doubtful and undescribed taxa cited from Southern Brazil

Amanita cf. crebresulcata Bas

Distribution - PR - Antonina.

Habitat and substrate - dense ombrophilous forest; terricolous.

Literature - de Meijer (2006: 11).

Comments - Wartchow \& Maia (2007) recorded this species from the state of Pernambuco in a tropical rain forest. The mycorrhizal association was not observed (Bas 1978).

Amanita sp. "A" subg. Amanita sect. Ovigerae Distribution - PR - locality unknown.

Habitat and substrate - 'restinga'; probably terricolous.

Literature - de Meijer (2001: 112, as Amanita sp. "A" subg. Amanita sect. Ovigerae).

Cantharellus cf. cinnabarinus (Schwein.) Schwein.

Distribution - PR - Antonina, Morretes, São José dos Pinhais.

Habitat and substrate - mixed ombrophilous forest, dense ombrophilous forest, 'restinga'; standing trunks of living dicotyledonous trees.

Literature - de Meijer (2001: 112, 2006: 13, 2008: 44, 372).

Comments - Cantharellus cinnabarinus is native or common in eastern North America, Mexico (Pilz et al. 2003), Europe, Africa and Asia (Watling et al. 2002). Pilz et al. (2003) also noted that $C$. cibarius is likely to include multiple cryptic species in different regions. According to Wartchow et al. (2012a), it is highly unlikely that the material with the epithet 'cinnabarinus' occurs naturally in tropical South America. For more information see Buyck et al. (2011) and Buyck \& Hofstetter (2011).

Clavulina aff. rugosa (Bull.) J. Schröt. Distribution- PR - Curitiba.
Habitat and substrate - mixed ombrophilous forest; terricolous.

Literature - de Meijer (2006: 14, 2008: 372).

Comments - Clavulina rugosa is putative ectomycorrhizal (de Meijer 2008). This species is frequently found under conifers and hardwoods. It is presumably mycorrhizal. Its close relatives in the genus Clavulina were confirmed to be mycorrhizal with Abies in Europe (Grebenc et al. 2009). The Dicymbe forest in South America has several Clavulina reported species (Henkel et al. 2012). It is widely distributed in North America and Europe (Kuo 2007 http://www.mushroomexpert.com/clavulina_ru gosa.html).

Cortinarius spp. /records from de Meijer (2001, 2006)

Distribution - PR - Cerro Azul, Cornélio Procópio. Tunas do Paraná.

Habitat and substrate - dense ombrophilous forest, seasonal semi-deciduous submontane/montane forest, and mixed ombrophilous forest; terricolous, occurring on dead wood.

Literature - de Meijer (2001: 112, as Cortinarius sp. A (subg. Sericeocybe sect. Pallidoviolaceae), de Meijer (2001: 112, as Cortinarius sp. B (subg. Sericeocybe sect. Sericeocybe), de Meijer (2001: 112, as Cortinarius sp. C (subg. Telamonia), de Meijer (2001: 112, as Cortinarius sp. D (subg. Telamonia), de Meijer (2001: 112, as Cortinarius sp. E (subg. Telamonia), de Meijer (2006: 16, as Cortinarius sp. A (subg. Sericeocybe sect. Sericeocybe), de Meijer (2006: 17, as Cortinarius sp. B (subg. Sericeocybe sect. Pallidoviolaceae).

Inocybe aff. cingulatipes (Corner \& E. Horak) Garrido Pinhais.

Distribution - PR - São José dos

Habitat and substrate - mixed ombrophilous forest; unknown substrate.

Literature - de Meijer (2006: 26).

Inocybe aff. conspicuospora Buyck \& Eyssart.

Distribution - PR - Fênix. 
Habitat and substrate - seasonal semideciduous, alluvial forest; unknown substrate.

Literature - de Meijer (2006: 26).

Inocybe aff. crassicystidiata Pegler

Distribution - PR - Antonina.

Habitat and substrate - dense ombrophilous forest; unknown substrate.

Literature - de Meijer (2006: 26).

Inocybe aff. incognita (E. Horak) Garrido

Distribution - PR - Morretes.

Habitat and substrate - dense ombrophilous forest; unknown substrate.

Literature - de Meijer (2006: 26).

\section{Inocybe cf. matrisdei Singer}

Distribution - PR - locality unknown. Habitat and substrate: 'restinga'; terricolous.

Literature - de Meijer (2001: 112).

Comments - Its association with any particular host tree and the full characteristics of the forest type have not been described (Singer et al. 1983).

Inocybe aff. pahangi (Corner \& E. Horak) Garrido

Distribution - PR - Guaraqueçaba.

Habitat and substrate - 'restinga'; unknown substrate.

Literature - de Meijer (2006: 26).

Inocybe aff. xerophytica Pegler

Distribution - PR - Paranaguá.

Habitat and substrate - 'restinga'; unknown substrate.

Literature - de Meijer (2006: 26).

Inocybe spp./records from de Meijer (2001)

Distribution - PR - locality unknown.

Habitat and substrate - dense ombrophilous forest, 'restinga', seasonal semideciduous submontane/montane forest; terricolous.

Literature - de Meijer (2001: 112, as Inocybe sp. A (subg. Inocybe sect. Inocybe), as Inocybe sp. B (subg. Inocybe sect. Inocybe), as Inocybe sp. $\mathrm{C}$ (subg. Inocybe sect. Petiginosae), as Inocybe sp. D (subg. Inocybe sect. Petiginosae).
Lactarius aff. necator (Bull.) Pers.

Distribution - RS - locality unknown. terricolous.

Habitat and substrate - forest;

Literature - Rick (1961a: 364, as $L$. adustus Rick), Singer (1953a: 83 as $L$. aductus).

Comments - As Singer (1953) noted, no specimens are preserved in Rick's herbaria.

Lactarius spp./records from de Meijer (2001)

Distribution - PR - locality unknown.

Habitat and substrate - dense ombrophilous forest; terricolous.

Literature - de Meijer (2001: 113), as Lactarius sp. "A" (aff. venezuelanus Dennis), as Lactarius sp. "B").

Phaeoclavulina cf. camellia (Corner) Giachini

Distribution - PR - Campina Grande do Sul, Colombo, Piraquara, São José dos Pinhais. Habitat and substrate: dense ombrophilous forest, mixed ombrophilous forest; terricolous, occurring on dead wood.

Literature - de Meijer (2001: 112, 2006: 41, 2008: 373, all as Ramaria cf. camellia Corner).

Phaeoclavulina aff. eumorpha (P. Karst.) Giachini

Distribution - PR - Fênix, Morretes, Paranaguá, Rio Branco do Sul, São José dos Pinhais.

Habitat and substrate - dense ombrophilous forest, mixed ombrophilous forest, seasonal semi-deciduous submontane/montane forest; unknown substrate.

Literature - de Meijer (2006: 41, as Ramaria aff. patagonica (Speg.) Corner).

Phaeoclavulina spp. / records from de Meijer (2006) Pinhais.

Distribution - PR: São José dos

Habitat and substrate - mixed ombrophilous forest; terricolous.

Literature - de Meijer (2006: 41, as Ramaria sp. "A" (subgen. Echinoramaria ser. Grandisporae). 
Ramaria cf. aureofulva Corner Pinhais.

Distribution - PR - São José dos

Habitat and substrate - mixed ombrophilous forest; unknown substrate.

Literature - de Meijer (2006: 41, 2008: 44, 373).

Ramaria cf. reticulata (Berk. \& Cooke) Corner var. macrospora Corner

Distribution - PR - Cornélio Procópio.

Habitat and substrate - seasonal semideciduous submontane/montane forest; unknown substrate.

Literature - de Meijer (2006: 41).

Russula cf. dennisii Singer ex Buyck

Distribution - PR - Antonina.

Habitat and substrate - dense ombrophilous forest; unknown substrate.

Literature: de Meijer (2006: 42).

Russula spp./records from de Meijer (2001)

Distribution - PR - locality unknown.

Habitat and substrate: dense ombrophilous forest, gallery forest in area of savanna, 'restinga'; terricolous.

Literature - de Meijer (2001: 113, as Russula sp. "A", as Russula sp. "B”, as Russula sp. “C”, as Russula sp. "D”).

Thelephora spp./records from de Meijer (2001)

Distribution - PR - locality unknown.

Habitat and substrate - mixed ombrophilous forest; occurring on dead wood.

Literature - de Meijer (2001: 113, as Thelephora sp. “A”).

Tricholoma cf. eucalypticum A. Pearson

Distribution - PR - Curitiba.

Habitat and substrate - Eucalyptus plantations; terricolous. 2006: 45)

Literature - de Meijer (2001: 113,

Tricholoma spp./records from de Meijer (2001)

Distribution - PR - locality unknown.

Habitat and substrate - mixed ombrophilous forest, Eucalyptus-plantations,
Pinus-plantations, seasonal semi-deciduous alluvial forest; terricolous.

Literature - de Meijer (2001: 112-113, as Tricholoma sp. "A" aff. imbricatum (Fr.: Fr.) Kummer; Tricholoma sp. "B" subg. Tricholoma sect. Genuina, and Tricholoma sp. "C". subg. Tricholoma sect. Tricholoma.").

Tylopilus spp./records from de Meijer (2001, 2006), Watling \& de Meijer (1997)

Distribution - PR - locality unknown.

Habitat and substrate - dense ombrophilous forest; terricolous or growing at the base of a living tree-fern trunk (Watling \& de Meijer 1997: 240).

Literature - de Meijer (2001: 112, 2006: 45, both as cf. Tylopilus sp.), Watling \& de Meijer (1997: 240).

Comments - Putative ectomycorrhizal, based on the fact that several species from the genus are known to be ectomycorrhizal (Halling et al. 2008, Tedersoo et al. 2010).

\section{Xerocomus aff. coccolobae Pegler}

Distribution - PR - Curitiba, Campina Grande do Sul, Mandirituba, São José dos Pinhais.

Habitat and substrate - dense ombrophilous forest, mixed ombrophilous forest; terricolous.

Literature - de Meijer (2001: 112, 2006: 45, as Xerocomus sp. "A"), Watling \& de Meijer (1997: 239, as Xerocomus cf. coccolobae Pegler).

Ectomycorrhizal fungi from Southern Brazil in perspective of the origin and plant partners

From a list of 144 species and affiliated species, over half ( 80 species) are considered to be introduced from other continents. In particular, from Santa Catarina and Rio Grande do Sul most of the recorded ECM species were introduced (Fig. 1). In Parana the dominance of native ECM species was observed mainly due to de Meijer's studies on macromycetes (Buyck \& de Meijer 1999, de Meijer 2001, 2006, 2008, Watling \& de Meijer 1997). That author described 37 potentialy ECM species from mixed ombrophilous forests (including Araucaria forest). 


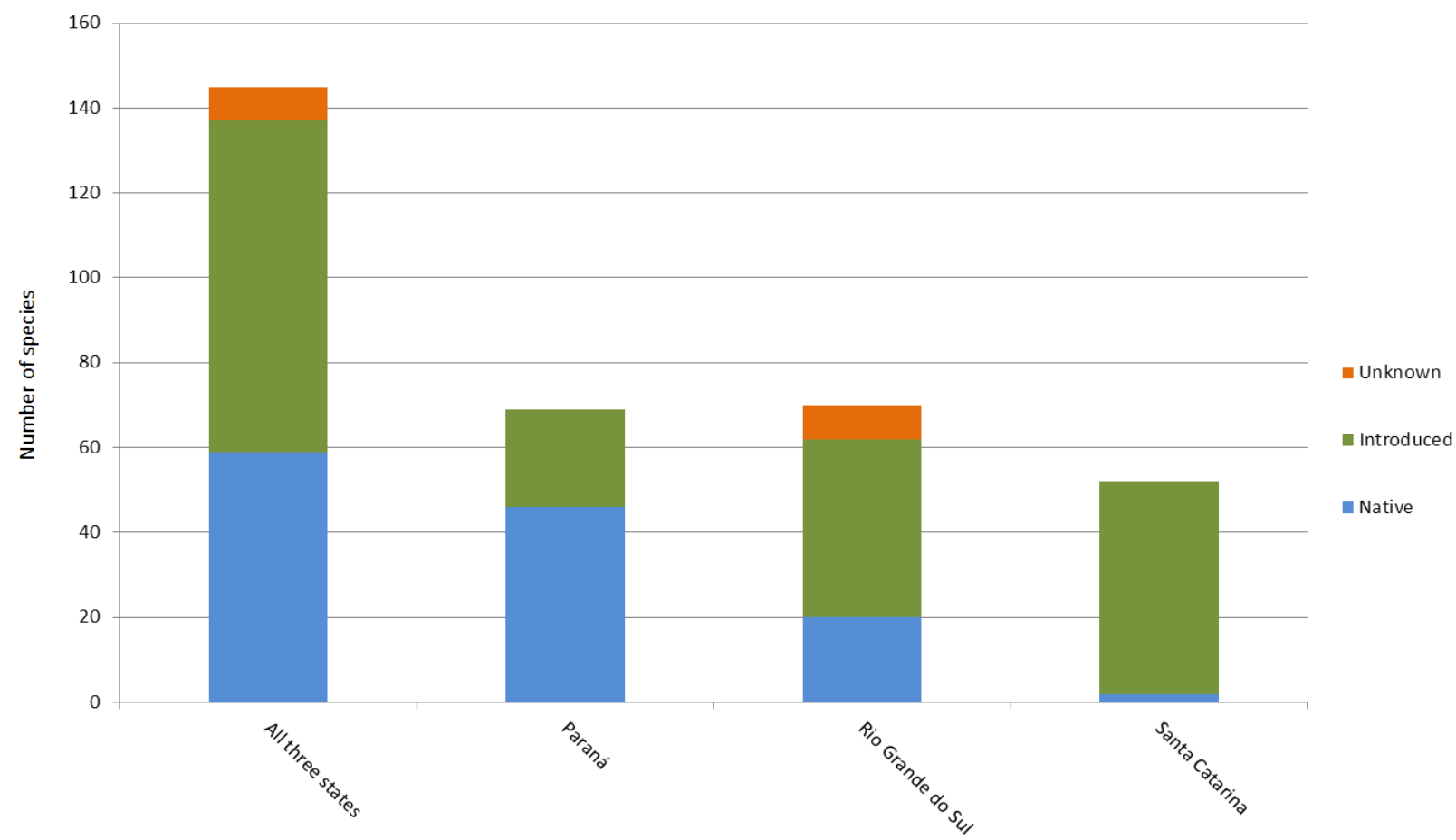

Fig. 1 - Number of introduced or native ectomycorrhizal fungal species recorded from the states of Parana, Rio Grande do Sul and Santa Catarina (Southern Brazil), and the total for all three states.

The differences among states (Fig.1) reflect the focus of research in past decades (Fidalgo 1962, 1968, Putzke 1994), in particular the mycological studies of introduced species plantations (Cortez et al. 2008a, Cortez et al. 2011a, Giachini et al. 2000, Giachini et al. 2004, Sulzbacher et al. 2010, Putzke 1999; in parts also Cortez et al. 2008, b, 2009, 2011b, Guzmán 1970, Putzke et al. 1994, Rick 1961a, b, Sobestiansky 2005) and the fact that plantations in the whole country cover about 5.98 million ha. These plantations where Eucalyptus spp. and Pinus spp. dominated as plant ECM partners, contributed equally to the number of recorded introduced ECM species. Most of the introduced ECM species listed were published in Giachini et al. (2000), who in particular surveyed the ECM fungal communities in the state of Santa Catarina. Their work resulted in 49 reported taxa, including three new described species to Southern Brazil. Other introduced plantation tree species (Acacia, Castanea, Populus, Salix) are of minor importance and of a low influence to the recorded ectomycorrhizal diversity and were only rarely available in the analysed references (Fig. 2).
Most of the ECM fungi introduced to Southern Brazil originate from North America and Europe. In Southern Brazil these fungi were found associated with Pinus spp. or recorded in association with both Pinus and Eucalyptus. As expected, most of the species originally known from Australia and New Zealand were found associated with Eucalyptus spp. plantations. Most of the ectomycorrhizal fungi associated with other broadleaf hosts were also native to Europe or North America (Fig. 3). As for origin, the rest of the world (Asia, Africa) did not contribute significantly to the number of ectomycorrhizal species observed in Southern Brazil.

\section{Conclusion}

In total 144 ectomycorrhizal or putatively ectomycorrhizal taxa were recorded in publications for the area of Southern Brazil (states of Rio Grande do Sul, Santa Catarina and Parana). In this region, climate, soil and vegetation are very different from the rest of the country (Dieckow et al. 2009). Thus, these conditions play a particular role in defining the relation between fungi and host. Over half of introduced plant partners (mainly Eucalyptus 


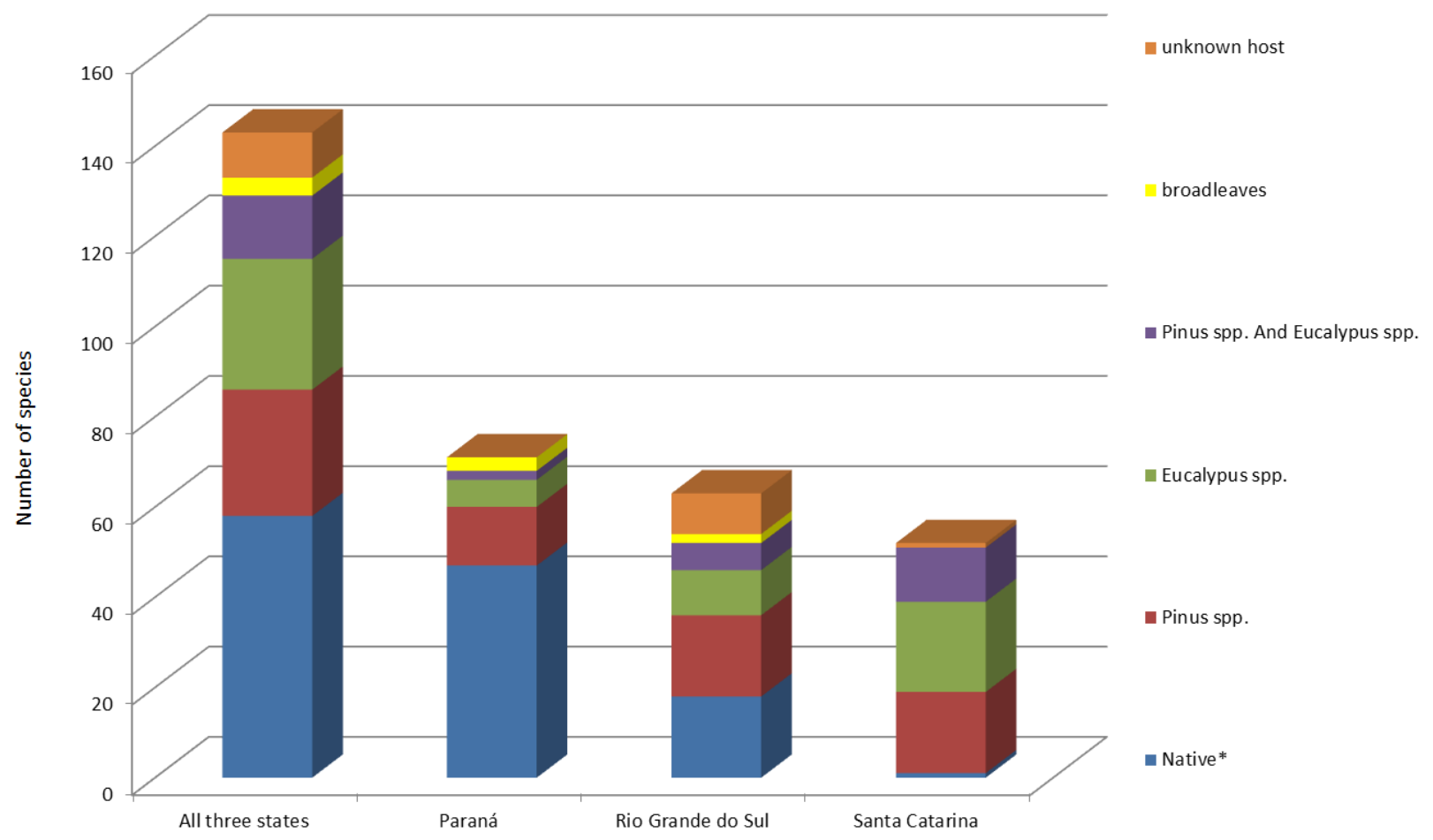

Fig. 2 - Number of introduced ectomycorrhizal fungal species recorded and potential ectomycorrhizal plant partners. Data based on published scientific papers summarised for three Southern Brazil states. Some species were found associated with more then one category of ectomycorrhizal partner or the host was unknown.

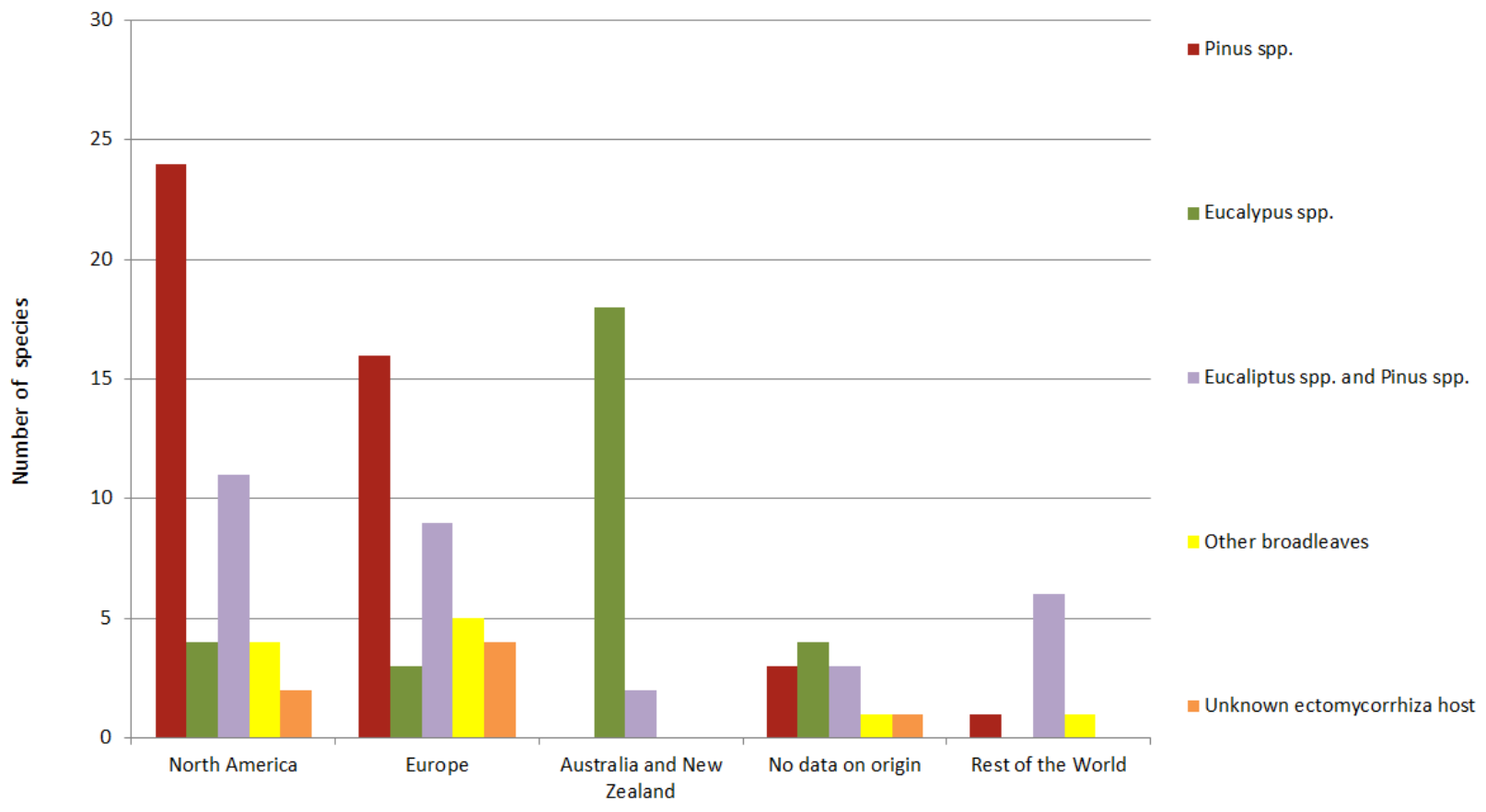

Fig. 3 - Global distribution/origin of the ectomycorrhizal fungi recorded in Southern Brazil. Species associated with hosts grouped either at the genus level, or at a higher level if available data were too general. The origin data is based on the combination of host and fungus origin. 
spp. and Pinus spp.) are well-known ECM in the Northern hemisphere or Australia and were introduced into Southern Brazil by means of the hand. Still, several of the listed species, are found only in South America (including Southern Brazil). For these, the majority has no definite record as being ectomycorrhizal and requires ECM description and/or molecular confirmation (sensu Agerer 1991). Therefore, there is still a need for further investigation in order to provide information on their ECM status, host partners range and ecological and seasonal distribution. Additionally, a number of the species still need more detailed taxonomic revision, including modern morphological analysis, application of molecular markers and phylogenetic species concept as a tool to better support their placement within a taxonomic classification. Future work aims to fill the missing gaps in knowledge of the diversity, mycorrhizal status and general ecology of the species listed here.

\section{Acknowledgements}

We are grateful to National Council for Scientific and Technological Development (CNPq - Brazil) and the Coordination for the Improvement of Higher Education Personnel (CAPES - Brazil) for their financial support. The work was co-financed by the Brazil Slovenia bilateral project (BI-BR/11-13-005) and the Research Programme Forest Biology, Ecology and Technology (P4-0107) of the Slovenian Research Agency. Special thanks go to Adriano Afonso Spielmann and Bruno Tomio Goto for their valuable suggestions to the manuscript. We thank to Admir José Giachini and Felipe Wartchow for constructive comments on the earlier version of the manuscript.

\section{References}

Agerer R. (1987-2006) - Colour atlas of Ectomycorrhizae. $\quad 1^{\text {st }}-13^{\text {th }}$ delivery. Einhorn Verlag, Schwäbisch Gmünd.

Agerer R. 1991 - Characterization of ectomycorrhiza. In: Norris JR, Read DJ, Varma AK, eds. Techniques for the study of mycorrhiza. Methods in Microbiology
23, 25-73.

Agerer R, Rambold G. 2004 - 2010 [first posted on 2004-06-01; most recent update: 2009-01-26]. DEEMY - An Information System for Characterization and Determination of Ectomycorrhizae. www.deemy.de - München, Germany.

Agerer R, Waller K. 1993 - Mycorrhizae of Entoloma saepium: parasitism or symbiosis? Mycorrhiza 3, 145-154.

Arora D. 1986 - Mushrooms Demystified: a Comprehensive Guide to the Fleshy Fungi. Berkeley, California: Ten Speed Press.

Arora D. 2008 - California porcini: Three new taxa, observations on their harvest, and the tragedy of no commons. Economic Botany 62, 356-375.

Ba AM, Thoen D. 1990 - First syntheses of ectomycorrhizas between Afzelia africana Sm. (Caesalpinioideae) and native fungi West Africa. New Phytologist 114, 99-103.

Baltazar JM, Ryvarden L, Gilbertoni, TB. 2010 - The genus Coltricia in Brazil: new records and two new species. Mycologia 102, 1253-1262.

Bas C. 1978 - Studies in Amanita. I. Some Amazonian species. Persoonia 10, 1-22.

Bas C, de Meijer AAR. 1993 - Amanita grallipes, a new species in Amanita subsection Vittadiniae from Southern Brazil. Persoonia 15, 345-350.

Baseia IG, Milanez AI. 2000 - First record of Scleroderma polyrhizum Pers. (Gasteromycetes) from Brazil. Acta Botanica Brasilica 14, 181-184.

Baseia IG, Milanez AI. 2002 - Rhizopogon (Gasteromycetes): hypogeous fungi in exotic forests from the State of São Paulo, Brazil. Acta Botanica Brasilica 16, 55-60.

Baseia IG, Cortez VG, Calonge FD. 2006 Rick species revision: Mitremyces zanchianus versus Calostoma zanchianum. Mycotaxon 95, 113-116.

Baseia IG, Silva BDB, Leite AG, Maia LC. 2007 - O gênero Calostoma (Boletales, Agaricomycetidae) em áreas de cerrado e semi-árido no Brasil. Acta Botanica Brasilica 21, 277-280. 
Beaton G, Pegler DN, Young TWK. 1985 -
Gasteroid Basidiomycota of Victoria State, Australia: 4. Hysterangium. Kew Bulletin 40, 435-444.

Bessette AE, Roody WC, Bessette AR. $2000-$ North American boletes: a color guide to the fleshy pored mushrooms, Syracuse University Press, Syracuse, New York. $396 \mathrm{p}$.

Bessette AE, Roody WC, Bessette AR, Dunaway DL. 2007 - Mushrooms of the Southeastern United States. Syracuse University Press. 373 p.

Bidartondo MI, Bruns TD. 2001 - Extreme specificity in epiparasitic Monotropoideae (Ericaceae): widespread phylogenetic and geographical structure. Molecular Ecology 10, 2285-2295.

Bigelow HE, Smith AH. 1962 - Clitocybe species from the Western United States. Mycologia 54, 498-515.

Binder M, Hibbett DS. 2002 - Higher level phylogenetic relationships of Homobasidiomycetes (mushroomforming fungi) inferred from four rDNA regions. Molecular Phylogenetics and Evolution 22, 76-90.

Binder M, Hibbett DS. 2006 - Molecular systematics and biological diversification of Boletales. Mycologia 98, 971-981.

Bottomley AM. 1948 - Gasteromycetes of South Africa. Bothalia 4, 473-810.

Bougher NL, Castellano MA. 1993 Delimitation of Hymenogaster sensu stricto and four new segregated genera. Mycologia 85, 273-293.

Bougher NL, Matheny PB. 2011 - Two species of Inocybe (fungi) introduced into Western Australia. Nuytsia 21, 139-148.

Bougher NL, Syme K. 1998 - Fungi of Southern Australia. University of Western Australia Press, Nedlands.

Breitenbach J, Kränzlin F. 1991 - Fungi of Switzerland 3: Boletes \& Agarics, 1st Part. Lucerne, Switzerland: Edition Mykologia.

Buyck B, de Meijer AAR. 1999 - Russula obtusopunctata, a new synonym for Lactarius venezuelanus. Mycotaxon 73, 267-273.

Buyck B, Eyssartier G. 1999 - Two new species of Inocybe (Cortinariaceae) from 
African woodland. Kew Bulletin 54, 675-681.

Buyck B, Hofstetter V. 2011 - The contribution of tef- 1 sequences to species delimitation in the Cantharellus cibarius complex in the southeastern USA. Fungal Diversity 49, 35-46.

Buyck B, Cruaud C, Couloux A, Hofstetter V. 2011 - Cantharellus texensis sp. nov. from Texas (USA), a Southern twin of $C$. cinnabarinus revealed by tef-1 sequence data. Mycologia 103, 1037-1046.

Castellano MA., Beever RE. 1994 - Trufflelike Basidiomycotina of New Zealand: Gallacea, Hysterangium, Phallobata, and Protubera. New Zealand Journal of Botany 32, 305-328.

Castellano MA., Muchovej JJ. 1996 - Trufflelike fungi from South America: Hysterangium sensu lato. Mycotaxon 57, $329-345$.

Chen DM., Taylor AFS, Burke RM, Cairney JWG. 2001 - Identification of genes for lignin peroxidases and manganese peroxidases in ectomycorrhizal fungi. New Phytologist 152, 151-158.

Cleland JB. 1928 - Australian fungi: notes and descriptions. - No. 7. Transactions and Proceedings of the Royal Society of South Australia 52, 217-222.

Coker WC, Couch JN. 1928 - The Gasteromycetes of the Eastern United States and Canada. University of North Carolina Press: Chapel Hill, NC. 201 p.

Corner EJH. 1968 - A monograph of Thelephora (Basidiomycetes). Nova Hedwigia, Beih. 27, 1-110.

Corner EJH, 1969 - Notes on cantharelloid fungi. Nova Hedwigia 18, 783-818.

Cortez VG. 2009 - Estudo sobre Fungos Gasteróides (Basidiomycota) no Rio Grande do Sul, Brasil. Universidade Federal do Rio Grande do Sul, Porto Alegre - unpublished PhD. Thesis.

Cortez VG, Coelho G. 2005 - Additions to the mycobiota (Agaricales, Basidiomycetes) of Rio Grande do Sul, Brazil. Iheringia 60, 69-75.

Cortez VG, Baseia IG, Guerrero RT, Silveira RMB. 2008a - Two sequestrate cortinarioid fungi from Rio Grande do Sul State, Brazil. Hoehnea 35, 513-518.
Cortez VG, Baseia IG, Silveira RMB. 2008b Gasteromicetos (Basidiomycota) no Parque Estadual de Itapuã, Viamão, Rio Grande do Sul, Brasil. Revista Brasileira de Biociências 6, 291-299.

Cortez VG, Sulzbacher MA, Baseia IG, Antoniolli ZI, Silveira RMB. 2011a New records of Hysterangium (Basidiomycota) in Eucalyptus plantations of south Brazil. Revista Brasileira de Biociências 9, 220-223.

Cortez VG, Baseia IG, Silveira RMB. 2011b Gasteroid mycobiota of Rio Grande do Sul, Brazil: Boletales. Journal of Yeast and Fungal Research 2, 44-52.

Dai YC, Zhang XQ, Zhou TS 2001 - New and noteworthy species of Hymenochaetaceae from China. Mycosystema 20, 16-21.

de Meijer AAR. 2001 - Mycological work in the Brazilian state of Paraná. Nova Hedwigia 72, 105-159.

de Meijer AAR. 2006 - Preliminary list of the macromycetes from the Brazilian state of Paraná. Boletim do Museu Botânico Municipal Curitiba 68, 1-55.

de Meijer AAR. 2008 - Notable Macrofungi from Brazil's Paraná Pine Forest. Colombo, PR: Embrapa Floresta.

de Meijer AAR, Baird RE. 1992 Macromycetes from the state of Paraná, Brazil. 3. Stipitate hydnums. Arquivos de Biologia e Tecnologia 35, 635-640.

Dieckow J, Bayer C, Conceição PC, Zanatta JA, Martin-Neto L, Milori DMBP, Salton JC, Mielniczuk J, Hernani LC. 2009 Land use, tillage, texture and organic matter stock and composition in tropical and subtropical Brazilian soils. European Journal of Soil Science 60, 240-249.

Dodge CW, Zeller SM. 1936 - Hydnangium and related genera reviewed. Annals of the Missouri Botanical Garden 23, 565598.

Dunstan WA, Dell B, Malajczuk N. 1998 The diversity of ectomycorrhizal fungi associated with introduced Pinus spp. in the Southern Hemisphere, with particular reference to Western Australia. Mycorrhiza 8, 71-79. 
Duponnois R, Founoune H, Masse D, Pontanier R. 2005 - Inoculation of Acacia holosericea with ectomycorrhizal fungi in a semiarid site in Senegal: growth response and influences on the mycorrhizal soil infectivity after 2 years plantation. Forest Ecology and Management 207, 351-362.

ECCF 2001 - Threatened Fungi in Europe. European Council for Conservation of Fungi $(\mathrm{ECCF})$ http://www.artdata.slu.se/Bern_Fungi/Be rn_Fungi.htm (last visited on 20.11.2012).

Fiaschi P, Pirani JR. 2009 - Review of plant biogeographic studies in Brazil. Journal of Systematics and Evolution 47, 477496.

Fidalgo O. 1962 - Rick, o Pai da Micologia Brasileira. Rickia 1, 3-9.

Fidalgo O. 1968 - Introdução à história da micologia brasileira. Rickia 3, 1-44.

Founoune H, Duponnois R, Bâ AM. 2002 Ectomycorrhization of Acacia mangium Willd. and Acacia holosericea A. Cunn. ex G. Don in Senegal. Impact on plant growth, populations of indigenous symbiotic microorganisms and plant parasitic nematodes. Journal of Arid Environment 50, 325-332.

Fuhrer B, Robinson R. 1992 - Rainforest fungi of Tasmania and Southeast Australia. CSIRO Press. Melbourne.

Garbaye J, Delwalle JC, Diangana D. 1988 Growth response of eucalypts in the Congo to ectomycorrhizal inoculation. Forest Ecology Management 24, 151157.

Giachini AJ, Castellano MA. 2011 - A new taxonomic classification for species in Gomphus sensu lato. Mycotaxon 115, 183-201.

Giachini AJ, Oliveira VL, Castellano MA, Trappe JM. 2000 - Ectomycorrhizal fungi in Eucalyptus and Pinus plantations in Southern Brazil. Mycologia 92, 11661177.

Giachini AJ, Souza LAB, Oliveira VL. 2004 Species richness and seasonal abundance of ectomycorrhizal fungi in plantations of Eucalyptus dunnii and Pinus taeda in
Southern Brazil. Mycorrhiza 14, 375381.

Gómez, LDP. 1996 - Basidiomicetes de Costa Rica: Xerocomus, Chalciporus, Pulveroboletus, Boletellus, Xanthoconium (Agaricales: Boletaceae). Revista de Biología Tropical 44, 59-89.

Grebenc T, Christensen M, Vilhar U, Čater M, Martin MP, Simončič P, Kraigher H. 2009 - Response of ectomycorrhizal community structure to gap opening in natural and managed temperate beechdominated forests. Canadian Journal of Forest Research 39, 1375-1386.

Grgurinovic, CA 1997. Larger fungi of South Australia. The Botanic Gardens of Adelaide and State Herbarium and the Flora and Fauna of South Australia Handbooks Committee, Adelaide, Australia.

Gruhn CM, Gruhn AV, Miller Jr OK. 1992 Boletinellus merulioides alters root morphology of Pinus densiflora without nycorrhizal formation. Mycologia 84, 528-533.

Guerrero RT, Homrich MH. 1999 - Fungos Macroscópicos Comuns no Rio Grande do Sul - Guia para Identificação. $2^{\mathrm{a}}$ ed. Porto Alegre: Ed. UFRGS.

Gurgel FE, Silva BDB, Baseia IG. 2008 - New records of Scleroderma from Northeastern Brazil. Mycotaxon 105, 399-405.

Guzmán G. 1970 - Monografia del género Scleroderma. Darwiniana 16, 233-407.

Guzmán G, Flora CA, Etelvina G, Transversin V. 2007 - First record of the genus Phlebopus (Basidiomycotina, Boletales) in Ecuador. Mycotaxon 99, 217-221.

Halling, RE, Mueller GM. 1998 - Macrofungi of Costa Rica (http://www.nybg.org/bsci/res/hall/exigu ua.html, last visited on 26.11.2012).

Halling RE, Mueller GM. 2005 - Common Mushrooms of the Talamanca Mountains, Costa Rica. Memoirs of The New York Botanical Garden, n. 90.

Halling RE, Osmundson TW, Neves MA. 2008 - Pacific boletes: Implication for biogeographic relationships. Mycological Research, 112, 437-447. 
Haug I, Wei $\beta$ M, Homeier J, Oberwinkler F, Kottke I. 2005 - Russulaceae and Telephoraceae form ectomycorrhizae with members of the Nyctanginaceae (Caryophyllales) in the tropical mountain rain forest of Southern Ecuador. New Phytologist 165, 923-936.

Henkel TW, Aime CM, Uehling JK, Smith ME. 2011 - New species and distribution records of Clavulina (Cantharellales, Basidiomycota) from the Guiana Shield. Mycologia 103, 883-894.

Henkel TW, Aime CM, Chin MML, Miller SL, Vilgalys R \& Smith ME. 2012 Ectomycorrhizal fungal sporocarp diversity and discovery of new taxa in Dicymbe monodominat forests of the Guiana Shield. Biodiversity and Conservation. DOI 10. 1007/s10531-0110166-1.

Hesler LR, Smith AH. 1979 - The North American Species of Lactarius. Ann Arbor, Michigan: The University of Michigan Press. 841 p.

Hibbett DS. 2006 - A phylogenetic overview of the Agaricomycotina. Mycologia 98, 917-925.

Hibbett DS, Pine EM, Langer E, Langer G, Donoghue MJ. 1997 - Evolution of gilled mushrooms and puffballs inferred from ribosomal DNA sequences. Proceedings of the National Academy of Sciences 94, 12002-12006.

Hosaka K, Bates ST, Beever RE, Castellano MA, Colgan III W, Domínguez LS, Nouhra ER, Geml J, Giachini AJ, Kenney SR, Simpson NB, Spatafora JW, Trappe JM. $2006-$ Molecular phylogenetics of the gomphoid-phalloid fungi with an establishment of the new subclass Phallomycetidae and two new orders. Mycologia 98, 949-959.

Issac S, Frankland JC, Watling R, Whalley AJS (eds). 1993 - Aspects of Tropical Mycology. Cambridge University Press, Cambridge, UK.

Jenkins DT. 1986 - Amanita of North America. Mad River, Eureka. 198 pp.

Jülich, W. 1984 - Kleine Kryptogamenflora Band II b/1. Die Nichtblätterpilze, Gallertpilze und Bauchpilze.
Karstedt F, Stürmer SL. 2008 - Agaricales em áreas de Floresta Ombrófila Densa e plantações de Pinus no Estado de Santa Catarina, Brasil. Acta Botanica Brasilica 22, 1036-1043.

Kasuya T, Takehashi S, Hoshino T, Noordeloos ME. 2010 - Entoloma aprile (Agaricales, Entolomataceae) new to Japan, with notes on its mycorrhiza associated with Populus maximowiczii in cool-temperate deciduous forests of Hokkaido. Sydowia 62, 205-223.

Keane PJ, Kile GA, Podger FD. (Editors) 2000 - Diseases and pathogens of eucalypts. CSIRO Publishing, Collingwood, VIC, Australia.

Kirk PM, Cannon PF, David JC, Stalpers JA. 2001 - Ainsworth \& Bisby's Dictionary of the Fungi. $9^{\text {th }}$ ed. Cambridge, United Kingdom: CAB International University Press.

Kirk PM, Cannon PF, Minter DW, Stalpers JA. 2008 - Dictionary of the Fungi. $10^{\text {th }}$ ed. Wallingford, UK: CABI.

Knudson H. 2006 - Arctic and Alpine Mycology 6. Copenhagen, Denmark: Museum Tusculanum Press.

Kotlába F. Pouzar Z, Ryvarden L. 1984 Some Polypores, rare or new to Cuba. Ceská Mykologie 38, 137-145.

Krieglsteiner GJ, Gminder A, Winterhoff W. 2000 - Die Großpilze BadenWürttembergs. 2. Eugen Ulmer, Stuttgart, 1-496 p.

Laessoe T. 1998 - Mushrooms (flexi bound). Eyewitness Handbooks. Dorling Kindersley, London, 304 pp.

Lago M, Castro ML. 2004 Macrobasidiomicetos asociados a Eucalyptus en la Península Ibérica. Fungi Non Delineati 27, 1-84.

Leelavathy KM, Manimohan P, Ganesh PN. 1986 - Sarcodon aroviridis - A stipitate Hydnum new to India. Sydowia 39, 124125.

Malajczuk N, Molina R, Trappe JM. 1982 Ectomycorrhizal formation of Eucalyptus. I. Pure culture synthesis, host specificity and mycorrhizal compatibility with Pinus radiata. New Phytologist 91, 467-482. 
Marmeisse, R, Gryta H, Jargeat P, FraissinetTachet L, Gay G, Debaud JC. 1997 - In.: Hebeloma. In: Cairney, J. W. G. \& Chambers, S. M. (Eds.) Ectomycorrhizal fungi: key genera in profile. Berlin: Springer, p. 89-127.

Martin F, Díez J, Dell B, Delaruelle C. 2002 Phylogeography of the ectomycorrhizal Pisolithus species as inferred from nuclear ribosomal DNA ITS sequences. New Phytologist 153, 345- 357.

Martín MP. 1996 - The genus Rhizopogon in Europe. Edic. Soc. Catalana Micol. Vol 5, 1-171.

Martín MP, Karen O, Nylund JE. 2000 Molecular ecology of hypogeous mycorrhizal fungi: Rhizopogon roseolus (Basidiomycotina). Phyton 40, 135-141.

Matheny PB, Curtis JM, Hofstetter V, Aime MC, Moncalvo J-M, Ge ZW, Yang ZL, Slot JC, Ammirati JF, Baroni TJ, Bougher NL, Hughes KW, Lodge DJ, Kerrigan RW, Seidl MT, Aanen DK, DeNitis M, Daniele GM, Desjardin DE, Kropp BR, Norvell LL, Parker A, Vellinga, EC., Vilgalys R, Hibbett DS. 2006 - Major clades of Agaricales: a multilocus phylogenetic overview. Mycologia 98, 982-995.

Mauhs J. 2000 - Tipos da coleção Fungi Rickiani. Pesquisas 50, 79-96.

McKenzie EHC, Johnston PR, Buchanan PK. 2006 - Checklist of fungi on teatree (Kunzea and Leptospermum species) in New Zealand. New Zealand Journal of Botany 44, 293-335.

Menolli JrN, Capelari M, Baseia IG. 2009a Amanita viscidolutea, a new species from Brazil with a key to Central and South American species of Amanita section Amanita. Mycologia 101, 395-400.

Menolli JrN, Asai T, Capelari M. 2009b Amanita coacta (Amanitaceae, Agaricales) with a key to Amanita species occurring in Brazil. Mycotaxon 107, 419-430.

Miller Jr OK, Lodge DJ, Baroni, TJ 2000 New and interesting ectomycorrhizal fungi from Puerto Rico, Mona, and Guana Islands. Mycologia 92, 558-570.
Miller SL, Larsson E, Larsson K-H, Verbeken A, Nuytinck J. 2006. Perspectives in the new Russulales. Mycologia 98, 960-970.

Molina R, Trappe JM. 1994 - Biology of the ectomycorrhizal genus, Rhizopogon. 1. Host association, host specificity and pure culture synthesis. New Phytologist 126, 653-675.

Moncalvo J-M, Vilgalys R, Redhead SA, Johnson JE, James TY, Aime MC, Hoffstetter V, Verduin SJW, Larsson E, Baroni TJ, Thorn RG, Jacobsson S, Clémençon H, Miller Jr OK. 2002 - One hundred and seventeen clades of euagarics. Molecular Phylogenetics and Evolution 23, 357-400.

Monclavo J-M, Nilsson RH, Koster B, Dunham SM, Bernauer T, Matheny PB, Porter TM, Margaritescu S, Weiß M, Garnica S, Danell E, Langer G, Langer E, Larsson E, Larsson K-H, Vilgalys R. 2006. The cantharelloid clade: dealing with incongruent gene trees and phylogenetic recostuction methods. Mycologia 98, 937-948.

Montecchi A, Sarasini M. 2000 - Funghi ipogei d'Europa. Fondazione Centro Studi Micologici dell Associazione Micologica Bresadola, Trento.

Moreau, P.-A. $2005-$ A nomenclatural revision of the genus Alnicola (Cortinariaceae). Fungal Diversity 20, 121-155.

Moreno-Arroyo B, Gómez J, Pulido E. 2005. Tesoros de nuestros montes. Trufas de Andalucía. Córdoba (Spain): Consejería de Medio Ambiente, Junta de Andalucía.

Moser M. 1980 - Kleine Kryptogamenflora, Vol. 2, Die Röhrlinge, Blätter-und Bauchpilze (Agaricales und Gastromycetales) Fischer-Verlag.

Mueller GM. 1991 - The Swedish taxa of Laccaria (Tricholomataceae) with notes on their distribution. Nordic Journal of Botany 10, 665-680.

Mueller GM. 1992 - Systematics of Laccaria (Agaricales) in the continental United States and Canada, with discussions on extralimital taxa and descriptions of extant types. Fieldiana: Botany, New Series 30, 1-158. 
Myers N, Mittermeier RA, Mittermeier CG, Fonseca GAB, Kent J. 2000 Biodiversity hotspots for conservation priorities. Nature 403, 853-858.

Neves MA, Capelari M. 2007 - A preliminary checklist of Boletales from Brazil and notes on Boletales specimens at the Instituto de Botânica (SP) herbarium, São Paulo, SP, Brazil. Sitientibus série ciências biologicas 7, 163-169.

Newton A, Holden E, Davy L, Holden E, Silverside A, Watling R, Ward SD. 2003 - Status, distribution and definition of mycologically important grasslands in Scotland. Biological Conservation 111, 11-23.

Nouhra E, Dominguez LS, Daniele GG, Longo S, Trappe JM, Claridge AW. 2008 Ocurrence of ectomycorrhizal, hypogeous fungi in plantations of exotic tree species in central Argentina. Mycologia 100, 752-759.

Nouhra ER, Hernandez ML, Pastor N, Crespo E. 2012 - The species of Scleroderma from Argentina, including a new species from the Nothofagus forest. Mycologia 104, 488-495.

Overbeck GE, Müller SC, Pillar VD, Pfadenhauer J. 2006 - Floristic composition, environmental ariation and species distribution patterns in burned grassland in Southern Brazil. Braz. J. Biol. 66, 29-41.

Overbeck GE, Müller SC, Fidelis A, Pfadenhauer J, Pillar VD, Blanco CC, Boldrini II, Both R, Forneck ED. 2007 Brazil's neglected biome: The South Brazilian Campos. Pers. Plant Ecol. Evol. Syst. 9, 101-116.

Petersen RH. 1988 - The Clavarioid Fungi of New Zealand. Bulletin of the New Zealand Department of Industrial Research 236, 1-170.

Phillips AR. 2006 - Mushrooms. Pan MacMillan. 384 p.

Pilz D, Norvell L, Danell E, Molina R. 2003 Ecology and management of commercially harvested chanterelle mushrooms. U.S. Department of Agriculture, Forest Service, Pacific Northwest Research Station Gen. Tech.
Rep. 83 pp. Portland, Oregon: U.S. Department of Agriculture, Forest Service, Pacific Northwest Research Station.

Putzke J. 1994 - Lista dos fungos Agaricales (Hymenomycetes, Basidiomycotina) referidos para o Brasil. Caderno de Pesquisa, Série Botânica 6, 1-189.

Putzke J. 1999 - O gênero Laccaria no Rio Grande do Sul. Caderno de Pesquisa Série Botanica 11, 3-13.

Putzke J. 2003 - Espécies de Tricholomataceae (Basidiomycota, Agaricales) no Rio Grande do Sul. Tese (Doutorado em Botânica) - Universidade Federal do Rio Grande do Sul, Porto Alegre unpublished $\mathrm{PhD}$. Thesis.

Putzke J, Maria L, Pereira AB. 1994 - Os fungos da família Boletaceae conhecidos do Rio Grande do Sul (Fungi, Basidiomycota). Caderno de Pesquisa, Série Botânica 6, 75-100.

Raithelhuber J. 1991 - Flora Mycologica Argentina: Hongos III. Stuttgart, add. ser. Metrodiana 1-500.

Rajchenberg M, de Meijer AAR. 1990 - New and noteworthy polypores from Paraná and São Paulo States, Brazil. Mycotaxon 38, 173-185.

Reid DA, Eicker A. 1991 - South African fungi: the genus Amanita. Mycological Research 95, 80-95.

Rick J. 1930 - Contributio IV ad monographiam Agaricearum Brasiliensium. Broteria 24, 97-118.

Rick J. 1937 - Agarici Riograndensis. Lilloa 1, 307-358.

Rick J. 1961a - Basidiomycetes eubasidii in Rio Grande do Sul - Brasilia. 5. Agaricaceae. Iheringia, série Botânica 8, 296-450.

Rick J. 1961b - Basidiomycetes eubasidii in Rio Grande do Sul. Brasilia. 6. Iheringia, série Botânica 9, 451-480.

Rinaldi AC, Comadini O, Kuyper TW. 2008 Ectomycorrhizal fungal diversity: separating the wheat from the chaff. Fungal Diversity 33, 1-45.

Rocha HR da, Manzi AO, Cabral OM, Miller SD, Goulden ML, Saleska SR, Coupe NR, Wofsy SC, Borma LS, Artaxo P, Vourlitis G, Nogueira JS, Cardoso FL, 
Nobre AD, Kruijt B, Freitas HC, von Randow C, Aguiar RG, Maia JF. 2009 Patterns of water and heat flux across a biome gradient from tropical forest to savanna in Brazil. Journal of Geophysical Research 114, 1-8.

Roody WC. 2003 - Mushrooms of West Virginia and the Central Appalachians. The University Press of Kentucky, p. 335.

Ryvarden L. 1976 - Polyporaceae of North Europe. Band 1.

Sanon KB, Bâ AM, Delaruelle C, Duponnois R, Martin F. 2009 - Morphological and molecular analyses in Scleroderma species associated with some Caesalpinioid legumes,

Dipterocarpaceae and Phyllanthaceae trees in Southern Burkina Faso. Mycorrhiza 19, 571-584.

SBS 2008 - Sociedade Brasileira de Silvicultura - www.sbs.org.br (last visited on 20.11.2012).

Singer R. 1945 - The Boletineae of Florida with notes on extralimital species. II. The Boletaceae (Gyroporoideae). Farlowia 2, 223-303.

Singer R. 1949 - The Agaricales in modern taxonomy. Lilloa 22, 1-832, [published in 1951].

Singer R. 1950 - Type Studies on Basidiomycetes. IV. Lilloa 23, 147-246.

Singer R. 1953a - Type Studies on Basidiomycetes VI. Lilloa 26, 57-159.

Singer R. 1953b - Four years of mycological work in Southern South America. Mycologia 45, 865-891.

Singer R. 1962 - Monographs of South American Basidiomycetes, especially those of the east slope of the Andes and Brazil V. - Gasteromycetes with agaricoid affinities (secotiaceous Hymenogastrineae and related forms). Boletín de la Sociedad Argentina de Botánica 10, 52-67.

Singer R. 1964 - Boletes and related groups in South America. Nova Hedwigia 7, 93132.

Singer R. 1986 - The Agaricales in Modern Taxonomy. $4^{\text {th }}$ ed. Koenigstein: Koeltz.

Singer R, Araújo I. 1979 - Litter decomposition and ectomycorrhiza in
Amazonian forests. Acta Amazonica 9, $25-41$.

Singer R, Aguiar, IA. 1986 - Litter decomposing and ectomycorrhizal basidiomycetes in an Igapó Forest. Plant Systematics and Evolution 153, 107-117.

Singer R, Digilio APL. 1957 - Las boletáceas austro-sudamericanas. Lilloa 28, 247268

Singer R, Araujo I, Ivory MH. 1983 - The ectotrophically mycorrhizal fungi of the neotropical lowlands, especially central Amazonia. Beih. Nova Hedwigia 77, 1352.

Smith AH, Zeller SM. 1966 - A preliminary account of the North American species of Rhizopogon. Memoirs of the New York Botanical Garden 14, 1-177.

Sobestiansky G. 2005 - Contribution to a macromycete survey of the States of Rio Grande do Sul and Santa Catarina in Brazil. Brazilian Archives of Biology and Technology 48, 437-457.

Stangl J. 1991 - Guida alla detreminazione dei funghi vol. 3. Inocybe. Saturnia. $437 \mathrm{pg}$.

Stivje T, de Meijer AAR. 1993 Macromycetes from the state of Paraná, Brazil. 4. The psychoactive species. Arquivos de Biologia e Tecnologia. 36, 313-329.

Sulzbacher MA, Putzke J, Putzke MTL, Cortez VG. 2007. - Nota sobre os fungos Agaricales (Basidiomycota) da Estação Ecológica de Aracuri, Esmeralda, Rio Grande do Sul, Brasil. Biociências 15, 143-153.

Sulzbacher MA, Cortez VG, Coelho G, Jacques RJS, Antoniolli ZI. 2010 Chondrogaster pachysporus in a Eucalyptus plantations of Southern Brazil. Mycotaxon 113, 377-384.

Taylor AFS, Martin F, Read DJ. 2000 - Fungal diversity in ectomycorrhizal communities of Norway Spruce [Picea abies (L.) Karst.] and beech (Fagus sylvatica L.) along north-south transects in Europe. In Schulze, Ernst-Detlef. Carbon and Nitrogen Cycling in European Forest Ecosystems. Ecological Studies. Berlin, Germany: Springer. pp. 343-365.

Tedersoo L, Suvi T, Beaver K, Saar I. 2008 Ectomycorrhizas of Coltricia and 
Mycosphere Doi 10.5943/mycosphere/4/1/5

Coltriciella (Hymenochaetales,

Basidiomycota) on Caesalpiniaceae, Dipterocarpaceae and Myrtaceae in Seychelles. Mycological Progress 6, 101107.

Tedersoo L, May TW, Smith ME. 2010 Ectomycorrhizal lifestyle in fungi: global diversity, distribution, and evolution of phylogenetic lineages. Mycorrhiza 20, 217-263.

Thaxter R. $1922-$ A revision of Endogonaceae. Proceedings of the American Academy of Art and Sciences 57, 291-351.

Thoen D. 1993 - Looking for ectomycorrhizal trees and ectomycorrhizal fungi in tropical Africa. In: Issac S. et al. (Eds.). Aspects of Tropical Mycology. Cambridge University Press.

Thoen D, Ba AM. 1989 - Ectomycorrhizas and putative ectomycorrhizal fungi of Afzelia africana $\mathrm{Sm}$ and Uapaca guineensis Müll. Arg. in Southern Senegal. New Phytologist 113, 549-559.

Toledo LD, Petersen RH. 1989 - A toxic Ramaria species from South America. Mycologia 81, 662-664.

Trappe JM, Schenck NC. 1982 - Taxonomy of the fungi forming endomycorrhizae. A. Vesicular-arbuscular mycorrhizal fungi (Endogonales, Pp. 1-9. In: Schenck NC (Ed.). Methods and principles of mycorrhizal research. APS Press, St. Paul, Minnesota.

Trierveiler-Pereira L, Baseia IG. 2009 - A checklist of the Brazilian gasteroid fungi (Basidiomycota). Mycotaxon 108, 441444.

Trudell S., Ammirati J. 2009 - Mushrooms of the Pacific Northwest. Timber Press Field Guide. 1-338 p.

Vellinga EC. 1986 - Some species of Laccaria from India. Sydowia 39, 224-229.

Veloso HP, Filho, ALR, Lima JCA. 1991 Classificação da vegetação brasileira, adaptada a um sistema universal. Fundação Instituto Brasileiro de Geografia e Estatística (IBGE), Rio de Janeiro.

Visnovsky SB, Laguette AG, Wang Y, Pitman AR. 2010 - Traceability of marketable Japanese Shoro in New Zealand: Using multiplex PCR to exploit phylogeographic variation among taxa in the Rhizopogon subgenus Roseoli. Applied and Environmental Microbiology 76, 294-302.

Vizzini A, Angelini C, Ercole E. 2012 - A new Neopaxillus species (Agaricomycetes) from the Dominican Republic and the status of Neopaxillus within the Agaricales. Mycologia 104, 138-147.

Vourlitis GL, Priante Filho N, Hayashi MMS, Nogueira JS, Caseiro FT, Campelo JrJH. 2002 - Seasonal variations in the evapotranspiration of a transitional tropical forest of Mato Grosso, Brazil. Water Resources Research 38, 10942004.

Wagner T, Ryvarden L. 2002 - Phylogeny and taxonomy of the genus Phylloporia (Hymenochaetales). Mycological Progress 1, 105-116.

Wartchow F. 2012a - Clavulina incrustata, a new species from Pernambuco, Brazil. Cryptogamie, Mycologie 33, 105-113.

Wartchow F. 2012b - Clavulina amazonensis, an Amazonian fungus discovered in the Atlantic Forest. Kurtziana 37 (in press).

Wartchow F, Cavalcanti MAQ. 2010 Lactarius rupestris - a new species from the Brazilian semi-arid region. Mycotaxon 112, 55-63.

Wartchow F, Maia LC. 2007 - The Neotropical Amanita crebresulcata Bas: new citation from northeast Brazil. Hoehnea 34, 131134.

Wartchow F, Tulloss RE, Cavalcanti MAQ. 2009 - Amanita lippiae - a new species from the semi-arid caatinga region of Brazil. Mycologia 101, 864-870.

Wartchow F, Buyck B, Maia LC. 2012a Cantharellus aurantioconspicuus (Cantharellales), a new species from Pernambuco, Brazil. Nova Hedwigia 94, 129-137.

Wartchow F, Maia LC, Cavalcanti MAQ. 2012b - Studies on Amanita (Agaricomycetidae, Amanitaceae) in Brazil: two yellow gemmatoid taxa. Nova Hedwigia 96, 61-71.

Watling R, de Meijer AAR. 1997 Macromycetes from the state of Paraná, 
Brazil. Edinburgh Journal of Botany 54, 231-251.

Watling R, Lee SS, Turnbull E. 2002 - The occurrence and distribution of putative ectomycorrhizal basidiomycetes in a regenerating South-east Asian rain forest. In: Tropical Mycology, vol. 1: Macromycetes (eds. Watling R, Frankland JC, Ainsworth AM, Isaac S, Robinson $\mathrm{CH}$ ). CABI Publishing, Oxon: 25-43.

Wilson AW, Hobbie EA, Hibbett DS. 2007 The ectomycorrhizal status of Calostoma cinnabarinum determined using isotopic, molecular, and morphological methods. Canadian Journal of Botany 85, 385-393.

Wolfe BE, Kuo M, Pringle A. 2012 - Amanita thiersii is a saprotrophic fungus expanding its range in the United States. Mycologia 104, 22-33.

Zeler SM, Dodge CW. 1929 - Hysterangium in North America. Ann. Mo. Bot. Gdn. 16, $83-128$.

Zhishu B, Guoyang Z, Taihui L. 1993 - The Macrofungus Flora of China's Guangdong Province. The Chinese University Press. 